\title{
تشالرز ساندرز بيرس \\ فيلسوف الأثر
}

\section{د. محمّلد حسين محجوب}

جامعة بنغازي/كلية الآداب

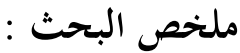

يروم هذا البحث؛ دراسة نشأة الفلسفة البراجماتية، من خلال دراسة جهود

$$
\text { مؤسسها " تشالرز ساندرز بيرس فيلسوف الأثر }
$$

Charles Sanders Peirce 1839-1914 Philosopher Impact وسوف يتم ذلك: عن طريق تحليل الرؤية التي طرحها ، والخلفية العلمية ، والفلسفية

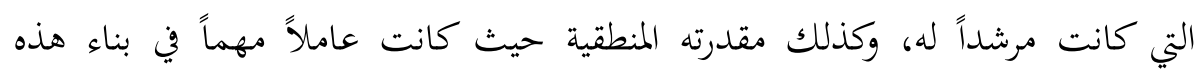
الفلسفة، وجاء هذا التحليل مرتكزاً على النقاط التالية: مقدمة حددت المحال الذي تقع فيه هذه الفلسفة، خلفية المؤسس العلمية والفلسفية، الفلسفة البراجماتية وأسسها الجوهرية، الإشارة إلى العديد من مقولات بيرس، الإشارة إلى بعض سمات هذه الفلسفة ، كما تضمن

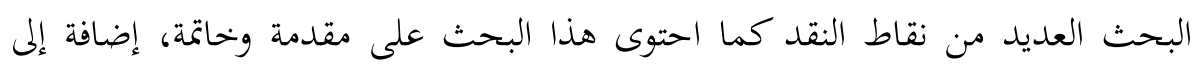
قائمة المراجع العلمية.

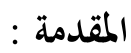

المحال الفلسفي، لمؤسس المذهب البراجماتي، هو الفلسفة المعاصرة؛ تلك الفلسفة

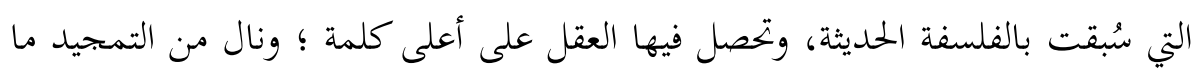

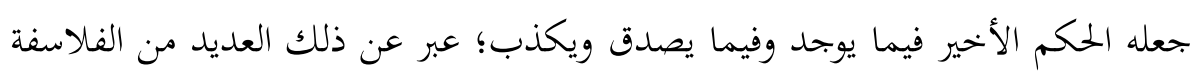
مثل:(ديكارت) و(سبينوزا) ولكن رجال فلسفة الحس لم يرق لهم ذلك مثل (لوك)و(هيوم)

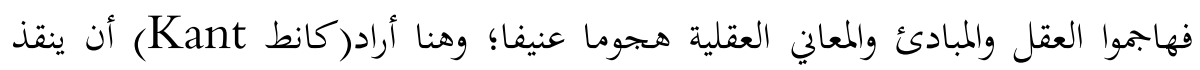


تلك المبادئ والمعاني باعتبارها بحرد صيغ جوفاء لتنظيم التجربة؛ في ظل هذا وذاك ولد مذهب التطور نتيجة لنظرية (دارون) فقال أصحابه: الحس، والعقل وظيفتان من وظائف

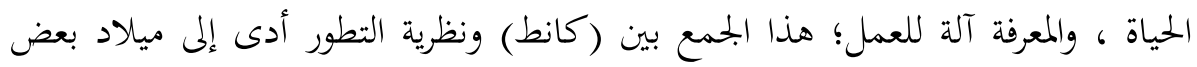
المذاهب ؛ العملية في الفلسفة. منها البراجماتية. وقد ازدهر هذا التيار على ما ترى عديد المراجع الفلسفية على الخصوص" في الولايات

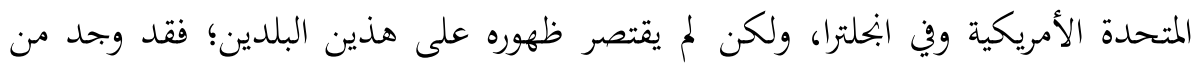
يمثله، في حدود عام 1900 م في ألمانيا ؛ حيث ظهر عند أصحاب المذهب التجريبي النقدي (كارل ماركس) و (لينين) و (جيورج سيمل) و(هانزفيهنجر 1852- 1933م)

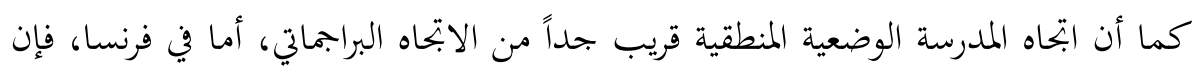

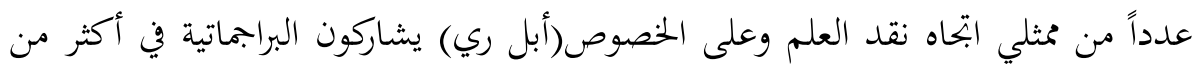
نقطة التقاء"(1) هذه المشاركة، والامتداد من طبيعة الفكر عموماً، وخصوصاً الأفكا، التي ينظر إليها على إعتبار أها ثورة ؛ضد الأفكار والتصورات السابقة، ومن هنا كان الاتحاه إلى نقد الفلسفات السابقة . إشكالية البحث : تتمثل إشكالية البحث في توضيح العلاقة بين العمل - الفكر أي محاولة التدليل

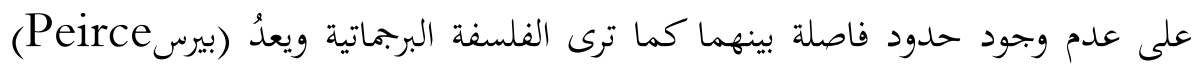
الفيلسوف المؤسس Funder للفلسفة البرجماتية، أو الفلسفة العملية، هذه الفلسفة التي تمزج بين: العمل، والفكر أي بمعنى آخر لا توجد حدود بين عمل، وفكر وأول رائد لها

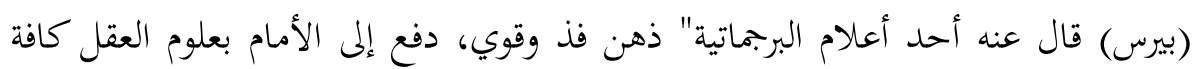

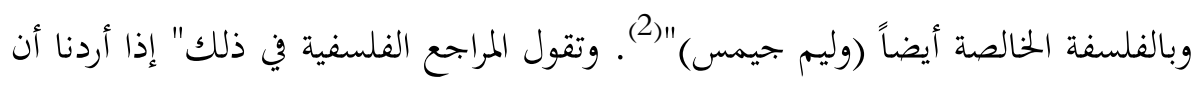

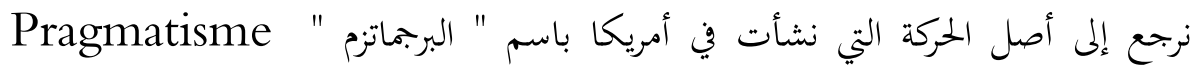
فلابد لنا أن نشير إلى مذهب الفيلسوف الأمريكي (بيرس) الذي استعمل الاصطلاح لأول

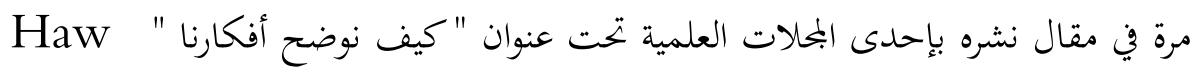


to make our Ideas Clear

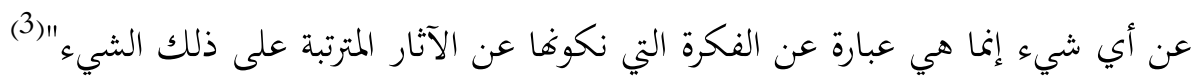

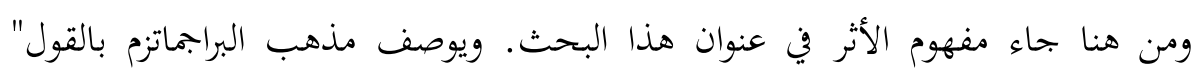

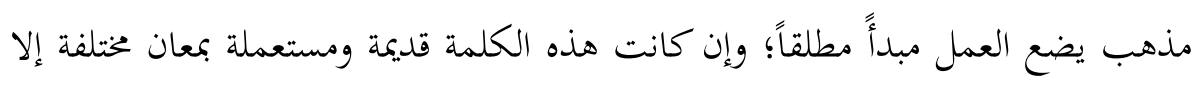
أن المعنى المعروف لها الآن ورد في مقال مشهور للفيلسوف الأمريكي تشارلس ساندرز بيرس" (4) (1)

\section{أهمية البحث :}

ترتبط أهمية البحث بتوضيح الدور الفلسفي الذي قام به مؤسس الفلسفة البراجماتية

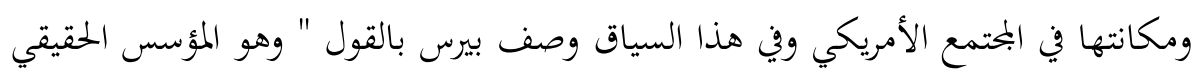

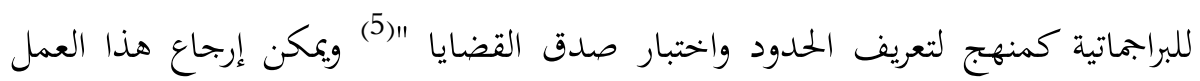
الذي قام به ( بيرس ) إلى الإحساس العام ، الذي انتاب الفلاسفة والمفكرين في فترة زمنية

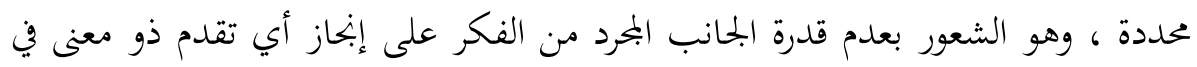

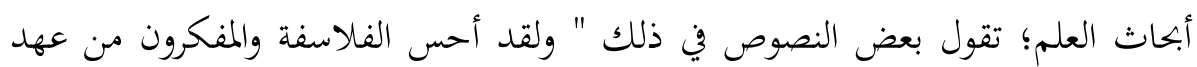
قريب نسبيا منذ حوالي قرن ونصف من الزمان بأن الفكر المحرد Vacated لابد أن ينتهي

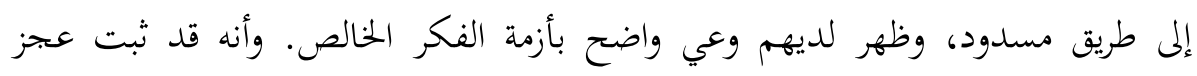
العقل في بحاله النظري الخالص عن الإنتهاء إلى رأي قاطع حاسم في المشكلات والي الأساسية

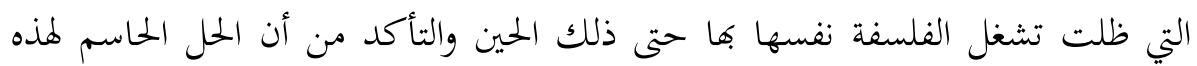
المشكلات إنما يكون في المحال العلمي لا النظري. وهذا العمل كان نتيجة جهود بحموعة

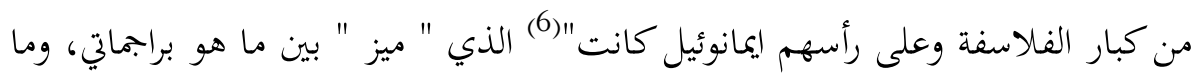
هو عملي، فالعملي ينطبق على القوانين الأخلاقية التي يعتبرها كانط أولية أو قبلية، بينما البراجماتي ينطبق على قواعد الفن وأسلوب التناول اللذين يعتمدان على الخبرة، ويطبقان في

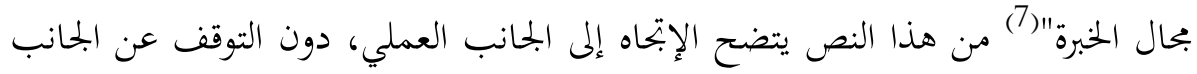

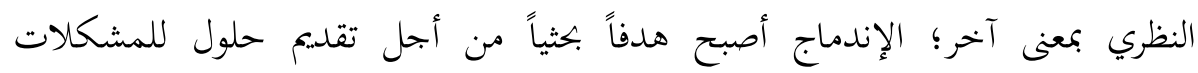


الفلسفية؛وهناك رأي آخر يقول في مسألة التسمية وانبثاق مفهوم البراجماتية" كلمة

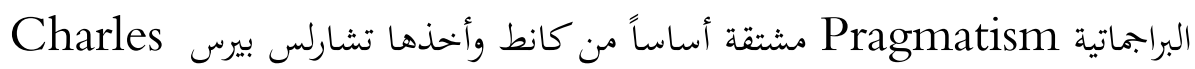
Concept عن كانط"(8) وهنا نشير إلى أن بيرس تعرف على هذا المفهوم S. perice

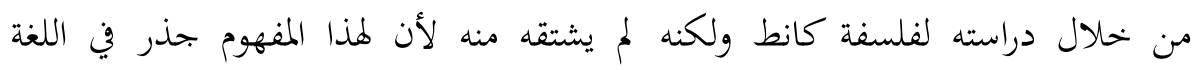
اليونانية. ولقد اهتم بيرس بالجانب المنطقي، في الفلسفة وخصوصاً المنطق الرمزي، وجاء

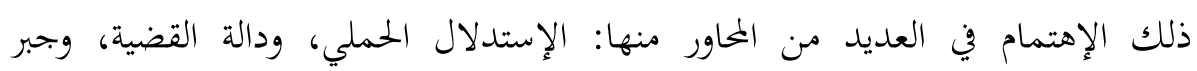
الأصناف، وعلاقة الإحتواء، و منطق العلاقات؛ كما ساهم في تعديل بعض نظريات المنطق التقليدي. ومع أن البحاث الذين تحدثوا عن هذه الفلسفة (البراجماتية) يقرون بالبداية لبيرس إلا أفهم يؤكدون على أن" هذه الفلسفة لم تتكامل إلا على يد (وليم جيمس * 1842Will James- 1910 م) الذي يعتبر الممثل الرئيسي لهذه المدرسة

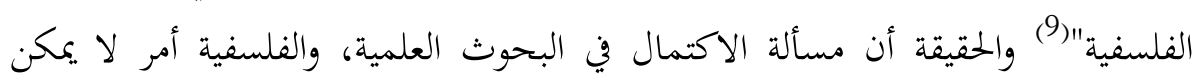
تقريره ولكن يمكن القول بأن الصورة المنطقية لهذه الفلسفة أصبحت واضحة ؛ ويشير مرجع آخر إلى أن هذا المفهوم Concept يرجع إلى (البركما) وهو مشتق من اللغة اليونانية، والذي يعني الفعل أو العمل وهي فلسفة عملية أو فلسفة فعل كما أها لا تَتم بالنتائج

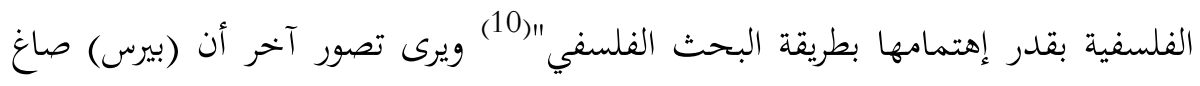
المفهوم نتيجة لتحديده دور الفكرة في البناء الفلسفي يقول" ولما انتهى بيرس إلى أن الفكرة

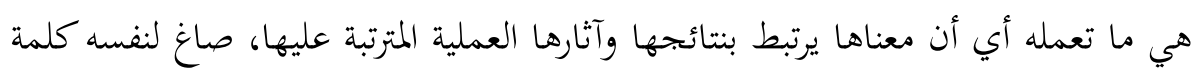
براجماتزم المشتقة من اللفظ اليوناني برجما Pragma الذي يدل على الفعل والعمل "(11) ويكاد يتفق جل الفلاسفة والباحثون على أن المفهوم Pragmatism "مشتق من اللفظ ينظ ئنس اليوناني Pragma وتعني العمل ويؤخذ منها كلمة عملي. وقد عرفها قاموس ويبستر العالمي Webster بأغها تيار فلسفي أنشأه تشارلس بيرس Charles Senders

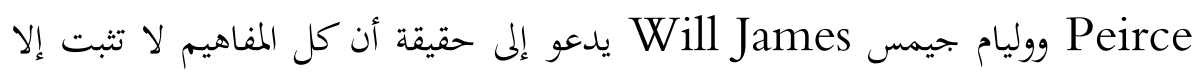

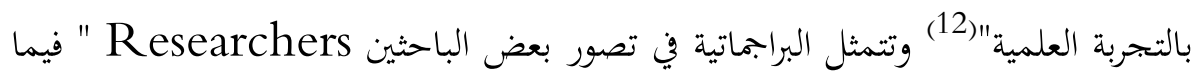


يتعلق بنظرية المعرفة، في نفي إمكانية المعرفة النظرية المحضة، وفي نفي المعرفة التأملية، وعموماً

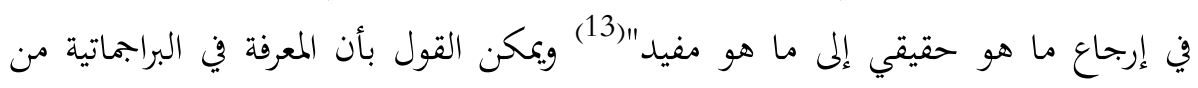

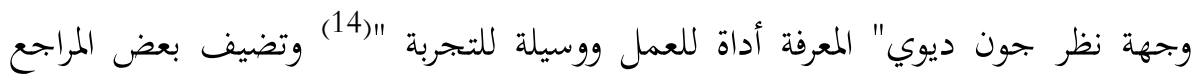

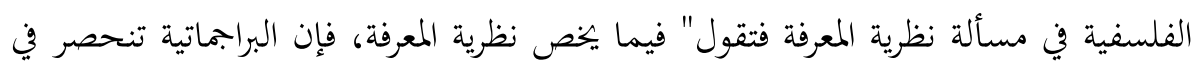

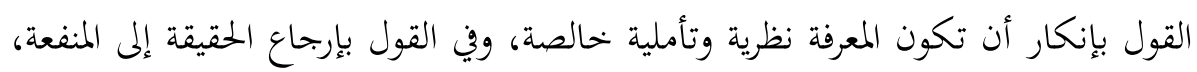

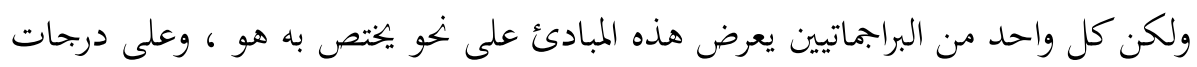

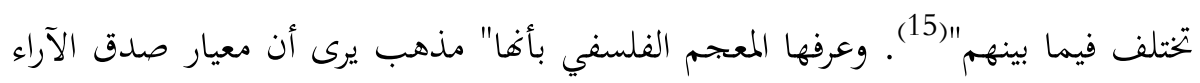

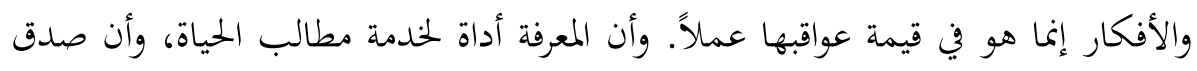

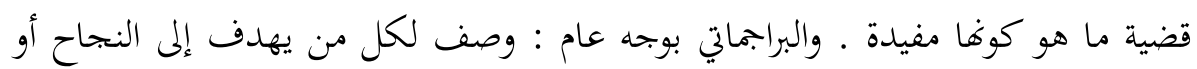
إلى منفعة خاصة"(16) ويمكن القول بأن بنية بيرس العلمية كان لها كبير الأثر في تصوره

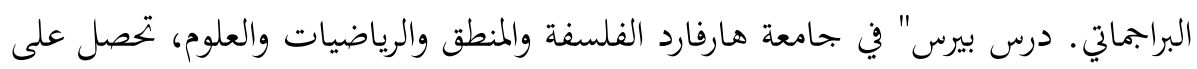

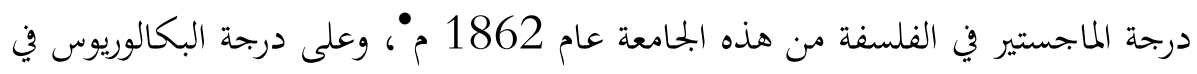
الكيمياء عام 1863 م"(17) وتقول بعض المراجع " أنه تخرج في هذه الجامعة سنة 1855

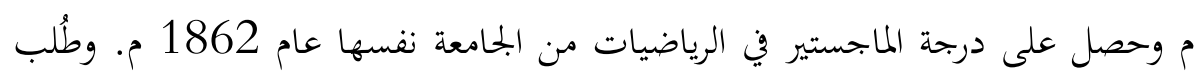

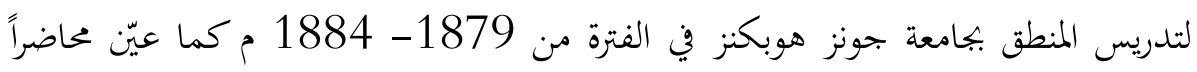
في فلسفة العلوم لمدة ثلاث سنوات بجامعة هارفارد وكذلك قام بالتدريس في معهد لوول Lowell المؤسس Establisher فأنت تفتح جل الأبواب التي فتحتها الفلسفة البراجماتية، بشكل شامل في النسق الذي يعبر عن هذه الفلسفة؛ على الرغم من وجود تباين في رؤى باحثيها لحظة ميلادها،أقصد هنا مرحلة تكوّها مع أعلامها وهم" أقطاب ثلاثة لا تكتمل صورة

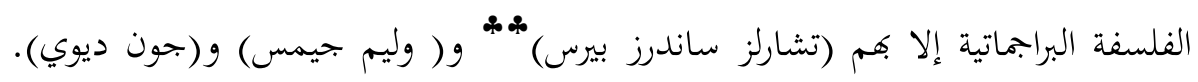

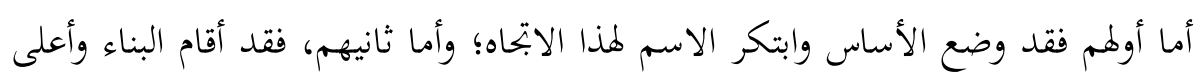

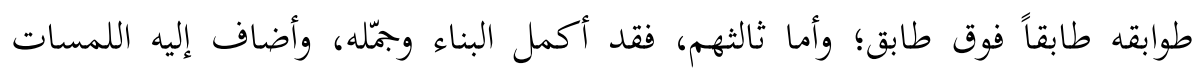


الأخيرة. ومن المفارقات الغريبة أن الرائد الأول وهو(بيرس) كان أكثر هؤلاء الثلاثة عمقاً،

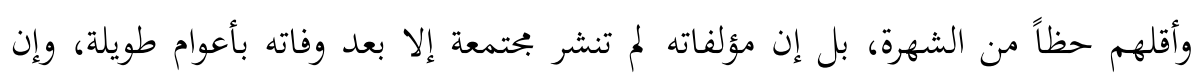

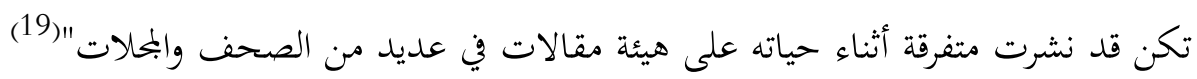
اتفق هؤلاء في أصول Principles الفلسفة البراجماتية ولكن لكل واحد منهم لوناً يتميز به عن البقية. وقد وصف جون ديوي البراجماتية بأها " فلسفة معاكسة للفلسفة القديمة

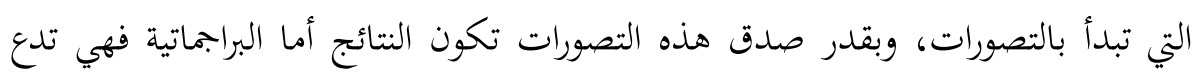
الواقع يفرض على البشر معنى الحقيقة ، وليس هناك حق أو حقيقة إبتدائية تفرض نفسها

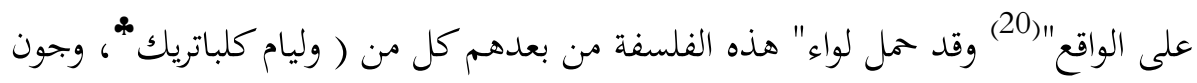

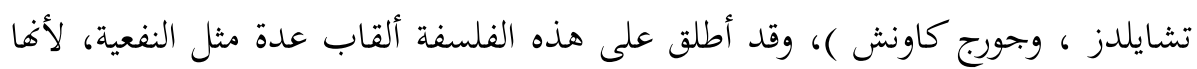

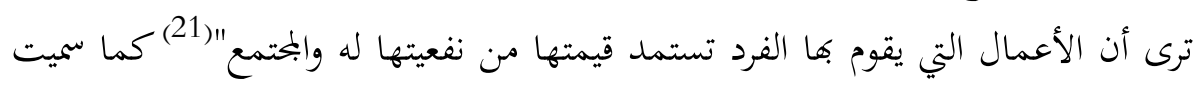

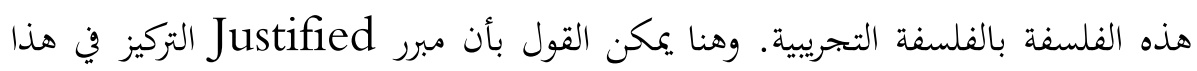

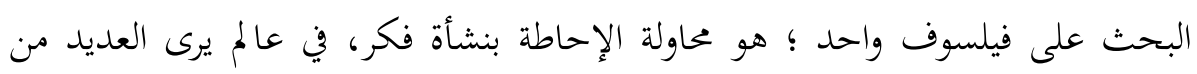
الباحثين، بأنه لم يتجذر فيه فكر فلسفي سابق، بما يشابه بعض المناطق مثل اليونان والهند،

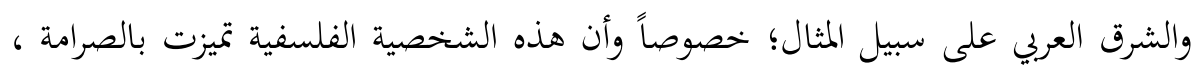
بداية من إختيار العنوان والتعديل الذي أجرته عليه ـ والدارس للفلسفة البراجماتية ، يلاحظ أها تقوم على أسس معينة، كما أها تتسم بسمات محددة في إطار البراجماتية؛ . ونشير هنا إلى أن هذا البحث قد اتبع المنهج التحليلي المقارن كما أنه استفاد من السياق التاريخي لهذه الفلسفة والفلسفات التي لها علاقة بها . أهداف البحث :

يهدف هذا البحث إلى العديد من الأهداف منها : توضيح العلاقة بين الفكر والعمل في نسق الفلسفة البراجماتية؛ أيضا توضيح الجهود القيمة للمؤسس في بحال المنطق التقليدي والرمزي، مع الإشارة إلى أن هذه الفلسفة وإن كانت جديدة في أمريكا إلا أن لها جذور في مناطق أخرى من العالم ولكنها كنسق تم تشكيلة في أمريكا . 


\section{أسس الفلسفة البراجماتية :}

تقوم الفلسفة البراجماتية، على بحموعة من الأسس،التي تُعد في ذات الوقت منابعها،

$$
\text { ودليل عملها، وبناء إشكالياتا ومنها : }
$$

1- " " المكانة التي تمتع بها العلم والمنهج العلمي في منتصف القرن التاسع عشر. 2- قوة تطابق النزعة التجريبية في الفلسفة المعاصرة مع الواقع.

3- قبول نظرية التطور البيولوجي.

4- قبول مُثل الديموقراطية الأمريكية."(22) ويمكن ذكر التصور التالي؛ لتوضيح النقطة

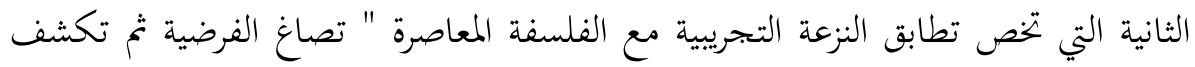
الملاحظة واقعة جديدة تجعل نمط التفسير مستحيلاً؛ وإذ ذاك تولد الحاجة إلى طريقة تفسير جديدة. فتصاغ فرضيات جديدة سيكون من الواجب تصحيحها أيضا. إن هذا التحول الديناميكي، وهذا التنامي في الفروض وتصحيحها لا يجري إعتباطا، بل على أساس التجربة والحاجة، وعلى أساس أن العالم نفسه يتحول بإستمرار وينمو على ولى

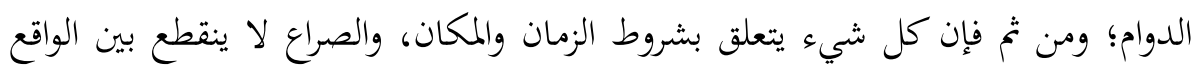

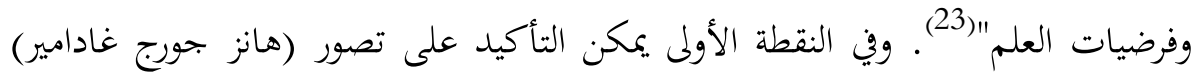
القائل" ليس ثمة فلسفة، بالمعنى الراهن، من دون العلم الحديث. والفلسفة بمعناها الأسمى هي دراسة العلم الأسمى، ومع ذلك علينا في النهاية أن نعترف بأن الفلسفة، من جهتها،

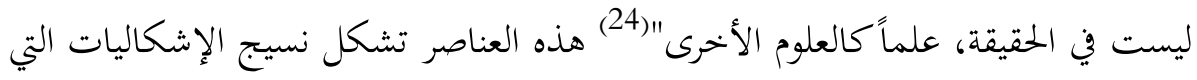
أفرزتا وعالجتها الفلسفة البراجماتية. ويمكن هنا الاستشهاد وبصورة موجزه بنظرية (بيرس) الموسومة (إمكان الخطأ Fallibilim ) والتي تقول بشكل موجز : " توجد ثلاثة أشياء لا نطمع في الوصول إليهاٍ هي اليقين المطلق، والدقة المطلقة، والعمومية المطلقة، في إطار المعرفة التجريبية ! أما معرفتنا للرياضيات، والمنطق، فيتوفر فيها اليقين وهذه الدقة (يبرر بيرس ذلك حسبما يذكر المرجع بالقول) ليس للكلمات التي لما دلالة بتريبية معنى دقيق

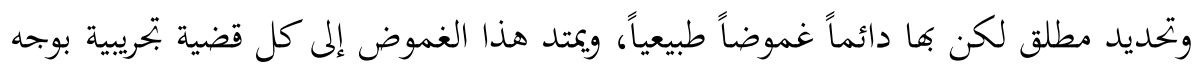


عام وكل قضايا الإدراك الحسي بوجه خاص؛ أن أي حكم من أحكام الإدراك الحسي أمر معقد يتضمن صدق قضايا أخرى مثل إفتراض صدق ما يقوله لنا علم وظائف الأعضاء

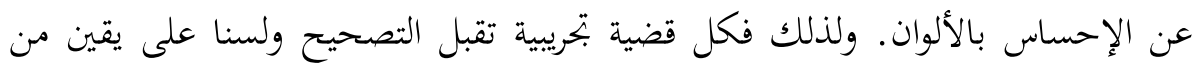
معناها وصدقها؛ نلاحظ أن هذا الموقف موقف فيلسوف علم ناقد يتجاوز الموقف

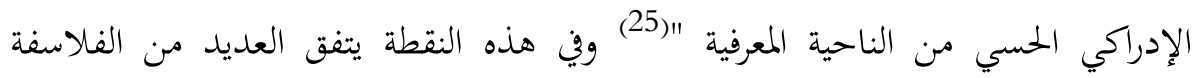
البراجماتيين " ويتفق (كليرنس أيرفنج لويس 1883 C.I.Lewis 1964 م ) في هذا منا مع الفلاسفة البراجماتيين وعلى رأسهم جون ديوي الذي يؤكد أنه لا يمكن أن نصل في في

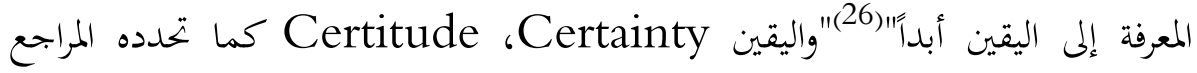
الفلسفية يعني"أن اليقين هو الاعتقاد الجازم المطابق الثابت، الذي لا يزول بتشكيك المشكك. وهو حالة ذهنية تقوم على إطمئنان النفس إلى الشيء مع الاعتقاد أنه كذا، وأنه

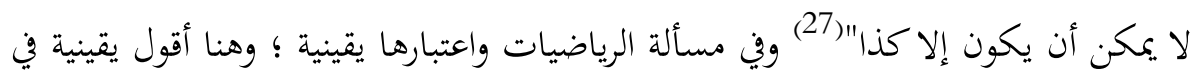
ذاتا؛ لأها لا تمنع وجود نوع آخر من الرياضيات، بمعنى أن هذا العلم قادر على إنتاج

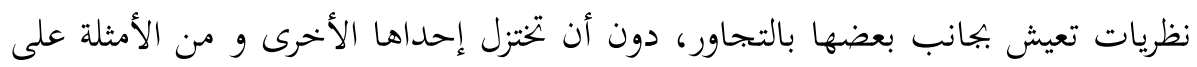
ذلك، علم الهندسة الذي أوجد ثلاث هندسات متجاورة: هندسة أوقليدس، وهندسة بهات

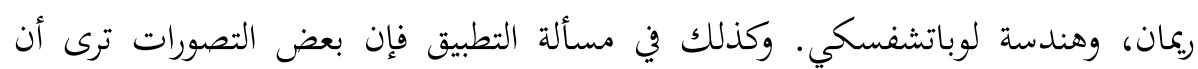

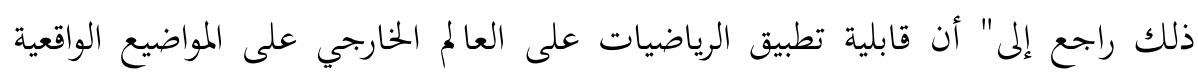

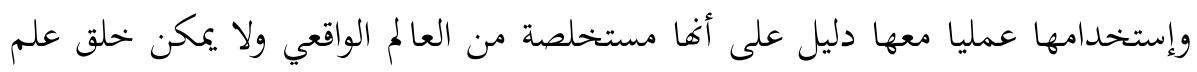

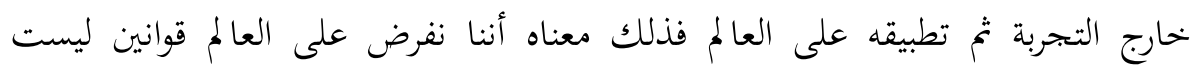
قوانينه"(28) هذا يشير إلى أن الجوانب العملية؛ هي التي أوجدت علم الريفي الرياضيات مثل: عملية تقسيم ومسح الأراضي. وتعتبر البراجماتية في بعض التصورات" مذهباً علمياً نفعيا ساعد في نشأهما إستخدام الطريقة العلمية أو ما ترتب عليها من نفع علمي صناعي؛ وجدت البراجماتية في النظام الرأسمالي الأمريكي خير تربة للنمو والازدهار، لأن الرأسمالية 
عامة تقوم على مبدأ المنافسة الفردية الحرة التي يرتبط فيها العمل المنتج النافع ـ وأصبحت

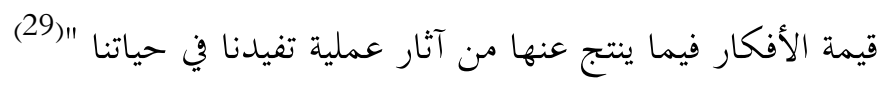
المنطق دليل البراجماتية :

تقول المراجع العلمية، عن حركة هذا الفيلسوف (تشالرز بيرس) العلمية وكيفية دخوله المحال الفلسفي" بدأ حياته الفكرية باحثاً في الكيمياء، تم دخل إلى الفلك والفيزيقا،اهتم

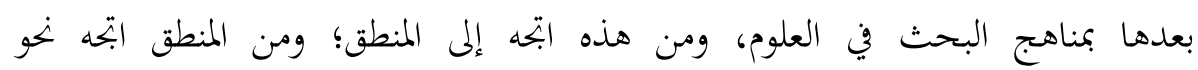
الفلسفة"(30) وتقول المراجع الفلسفية عن جهوده في المنطق الرمزي" أن مساهماته في المنطق

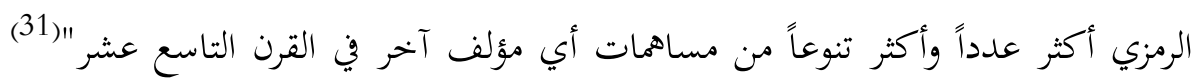
وفي مسألة المنطق التقليدي، اهتم بطبيعة القضية الحملية والإستدلال حيث اعتبر علاقة الترات التضمن التي كان يسميها Illative relation علاقة منطقية أساسية" وهي ما نعبر عنه بالحروف(إذا .....إذن) استخدم هذه العلاقة أولاً لتقديم فهم جديد للقضية الحملية، وفي ذلك يقول" لقد أعلنت منذ عام 1867م أنه توجد علاقة منطقية أساسية وهي التضمن ...ليست القضية عندي سوى إستدلال عزلنا عنه تقرير مقدمته الكبرى ونتيجته،

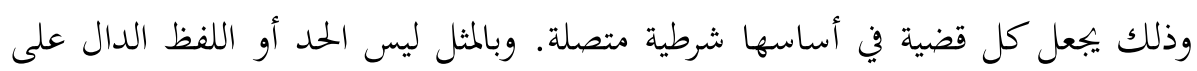
صنف عندي سوى قضية خلا مكان موضوعها أو أن موضوعها غير محدد ...تعطي هذه النظرية للمنطق وحدة كبرى" فالقضية كل إنسان فان مثلاً تعني أنه" إذا كان س حاصلاً

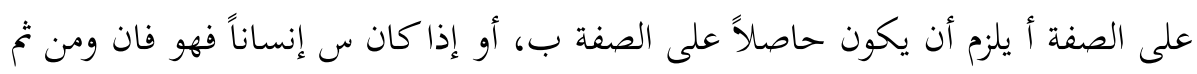

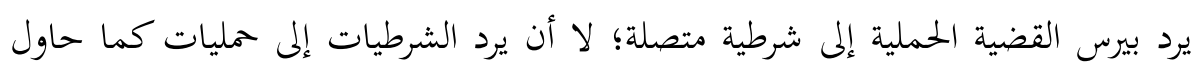

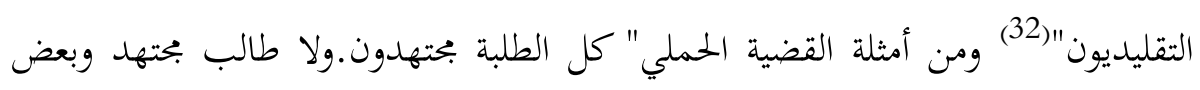
الطلبة بحتهد وليس بعض الطلبة بحتهد، الموضوع في القضايا السابقة واحد وهو الطلبة

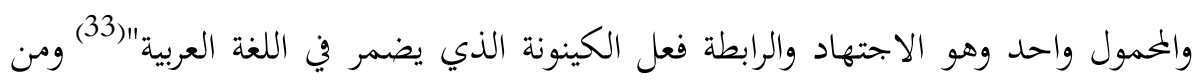
أمثلة القضية الشرطية المتصلة" إذا تبع السائقون التعليمات انتظم المرور . في القضية السابقة المقدم Antecedent سبب للتالي Consequent. ويميز بعض المناطقة ما هو 
نسبي وما هو مطلق في هذا النوع من القضايا المنطقية فالشرطية المتصلة النسبية هي التي تجعل علاقة الشرط بين المقدم والتالي في إطار زماني مكاني مثل إذا عرفت مفتاح الشفرة

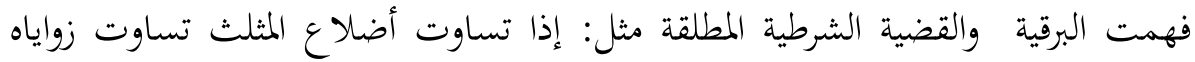
"(34) هذا في الهندسة الاقليدية. الفرق بين القضيتين خروج القضية المطلقة عن إطار الزمان

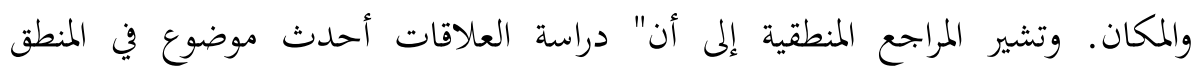

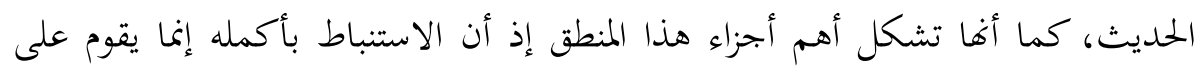

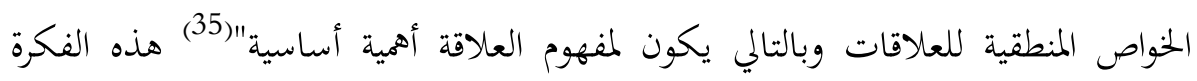
المنطقية، من الأفكار التي أبدعها بيرس كما تؤكد ذلك السياقات التاريخية، فقد ذكرها برادلي في كتابه المنطق الذي نشر عام 1883 م كما دوّن فيمة هذه الفكرة في كتابه التصورات Begeriffsschrift الذي نشر عام 1879 م وكانت هذه الفكرة واضحة عند رسل، وتقوم هذه الفكرة على تصور بيرس للعلاقة حيث يقدم التعريف التالي" إذ

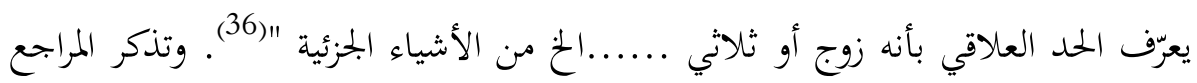

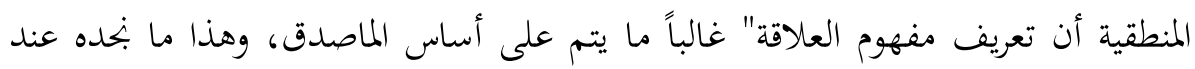
معظم المناطقة مثل: بيرس، فلفظ يحب يتطلب أن يكون هناك فردان يرتبطان بهذه العلاقة

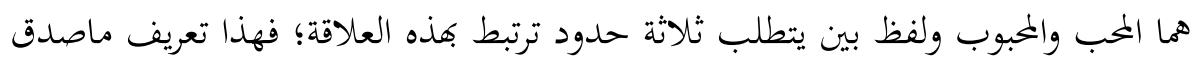

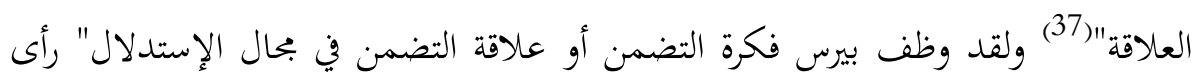
بيرس أن الحد والقضية لا يختلفان من حيث التركيب المنطقي وإنما من حيث أن القضية

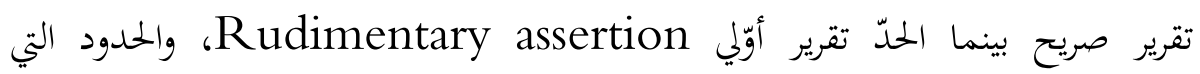

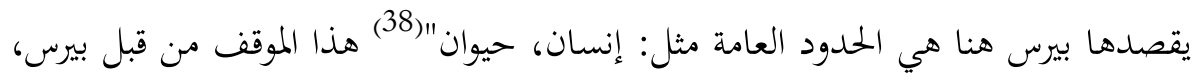
مبني على تصور مفاده: أن المنطق التقليدي قد تعسف في التمبيز بين الحدٌّ والقضية؛ والقضية والاستدلال. ويرى بيرس أن القضية والاستدلال من تركيب منطقي واحد وأن

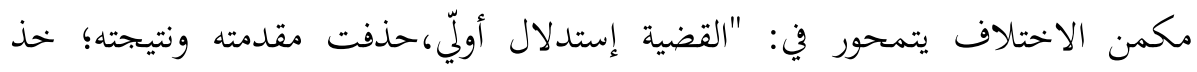
القضية: كل إنسان فان، والاستدلال: سُقراط إنسان، وكل إنسان فان، إذا سقراط فان. 
نعبر عن القضية بقولنا إذا س إنساناً فهو فان ونعبر عن الاستدلال بقولنا س إنسان وهو إذاً فان؛ الفرق بين الصورتين السابقتين: أن الأولى لا تنطوي على تقرير صريح، وإنما على إسلى

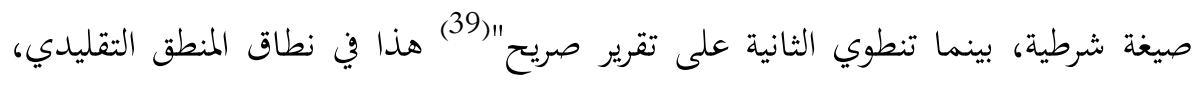

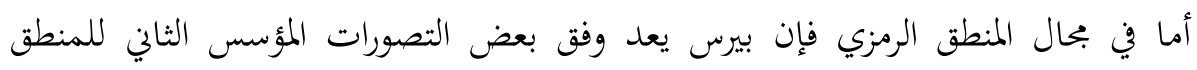

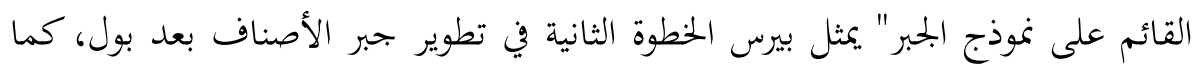

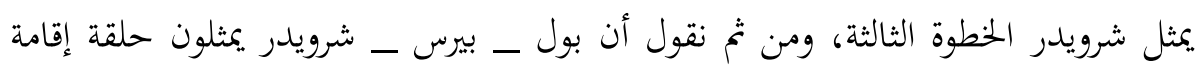
المنطق على نموذج الجبر" (40) وترى بعض التصورات أن رؤية بيرس في نظرية الإعتقاد Belief مؤسس البراسجماتية. التي تقوم على نظرية الاعتقاد و إلى هذه النظرية الإعتقادية يستند

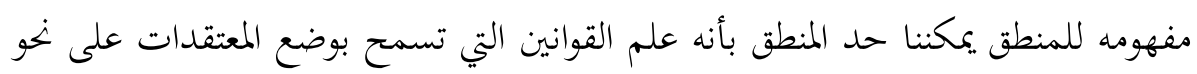
ثابت"(41) وفي جبر الأصناف" ميزّ بيرس بين العمليات الحسابية التي تعبر عن علاقات منطقية كالجمع والضرب، والعمليات الحسابية التي لا تعبر عن تلك العلاقات كالطرح والقسمة، وهو تمييز لم يفطن إليه بول . وقد صاغ بيرس بعض قوانين جبر الأصناف منها:

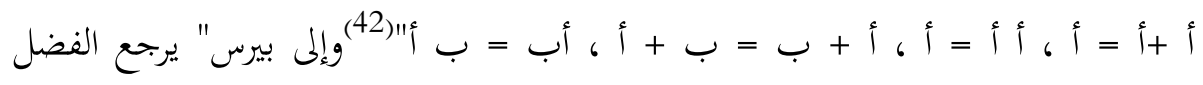

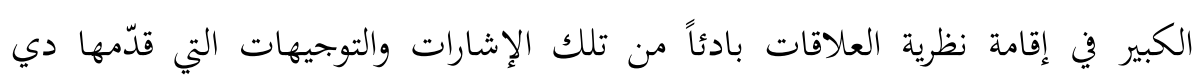
مورجان.ورأى بيرس إمكان النظر إلى أي قضية حتى الحملية على أها قضية علاقة، إذ يمكن

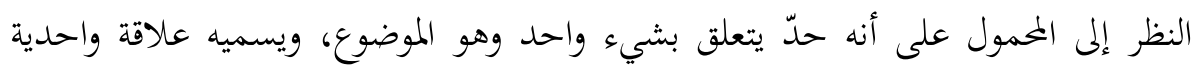
Monadic relation ومن ثم نظر إلى أيّ حدّ عام على أنه ينطوي على علاقة واحدية، أي علاقة بشيء واحد

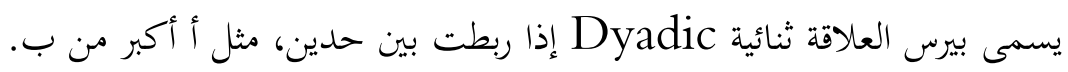

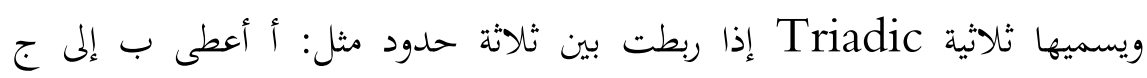
ومتعددة الأطراف Polyadic إذا ربطت بين عدد أكبر من الحدود. ورسل يستخدم

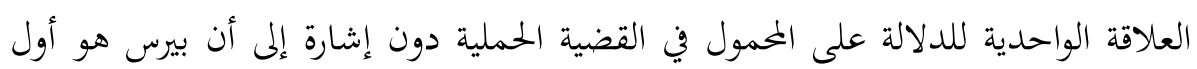


من استخدم التعبير"(43) ولقد عارض رسل" هذا الاتحاه الماصدقي لتعريف العلاقة، لأن قيام مثل هذا التعريف وإن كان في حد ذاته ممكناً من الناحية الفنية لا يوجه إنتباهنا مباشرة

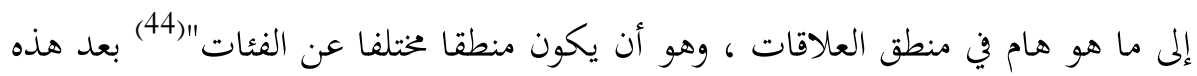
الإشارة إلى جهود بيرس في المنطق ننتقل لجهوده في بناء الفلسفة البراجماتية.

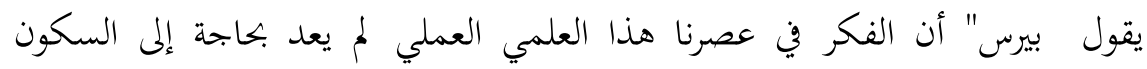
والظلام اللذين كان يستعين بهما فيما مضى، بل أصبحت حياته مرتبطة بتجارب المعامل

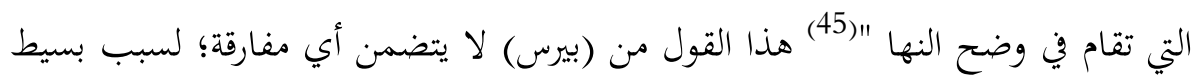

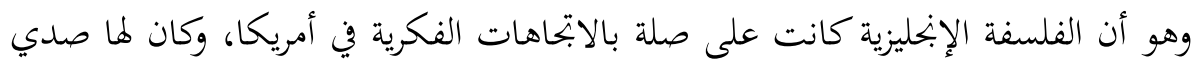
كبيراً قبل أن تظهر فلسفة بيرس وبشكل متعين ، لأن فلاسفة مثل، ( لوك ) و (هيوم )

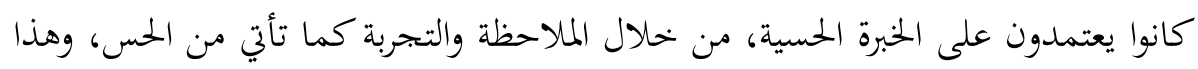
الأمر ربما يبرر القول بأنه لا جديد عند بيرس في الإتحاه إلى الواقع ، فهيوم على سبيل

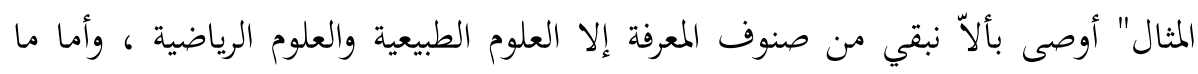

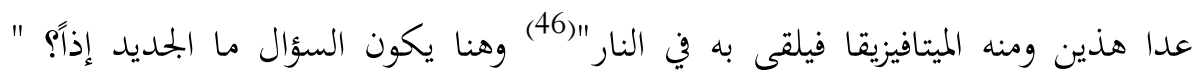
الجدديد في بعض الرؤى هو في إسستبدال النظر إلى المستقبل بالنظر إلى الماضي. التجريبية

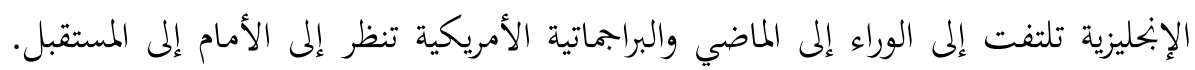

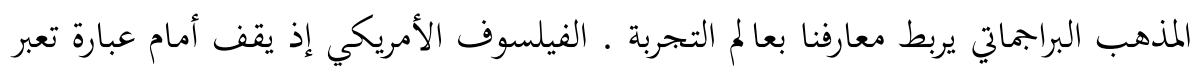

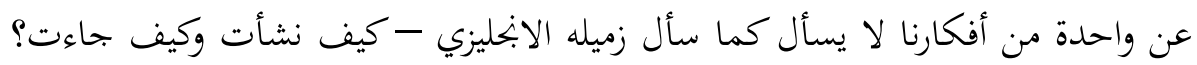

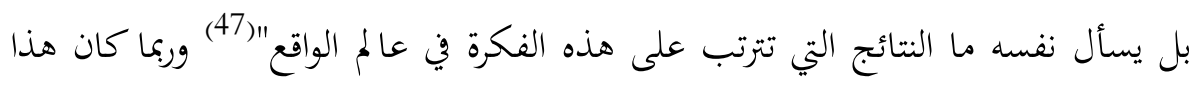
الاتحاه هو ما دعا بعض مؤلفي المعاجم الفلسفية إلى وصف (بيرس) بأنه منشئ الذرائعية تقول في ذلك" وأرسى بيرس دعائم الذرائعية في هذه الدراسة(كيف نوضح أفكارنا)التي

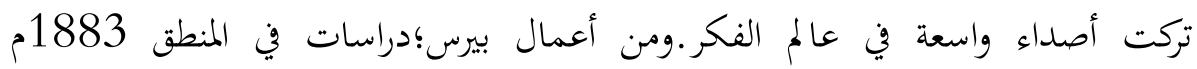

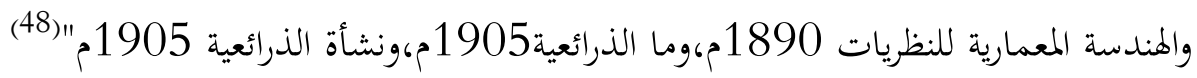
كانت جلّ اعماله تتجه للمستقبل، هذه السمة الجوهرية(إستشراف المستقبل) هي التي 
دعتنا للكتابة، والبحث في هذه الفلسفة؛ لأن الفلسفة لم تعد بحاجة إلى صيغ كلامية جوفاء، ولكنها بحاجة إلى جمل، وكلمات تدفع للعمل للسلوك المنتج، بحاجة إلى جمل بتعل القارئ يحس بأن عليه واجب الفهم أولاً، وواجب نقل الرغبة في الفهم للغير ثانياً، وبحاجة إلها

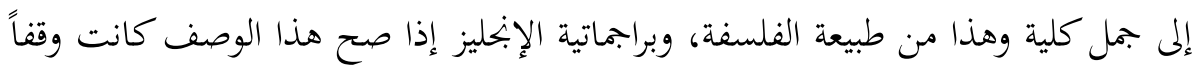
على الأخلاق؛ كما في مذهب المنفعة عند (مل) والذي ينص على أن الفعل يكون فضيلة، أو رذيلة حسب ما يترتب عليه من نتائج تشقي الناس أو تسعدهم؛ والعلم حيث كان يسعى إلى أن يكون مقياس الفرض العلمي مطابقة نتائجه للواقع. أما ما يدعو إليه (بيرس)

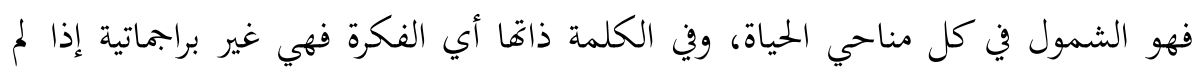

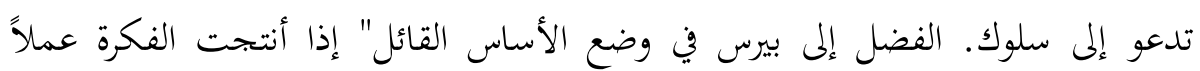

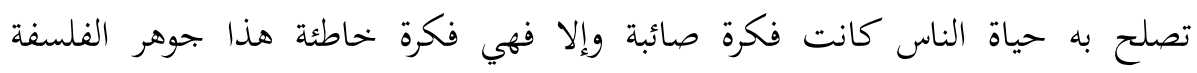

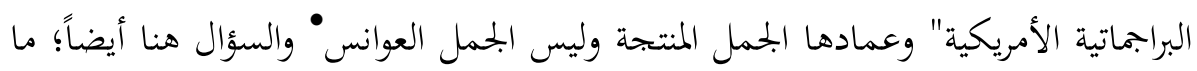
هي مشكلة بيرس التي يريد تقديم حل لها؟ بتيب بعض المراجع عن السؤال بالقول"

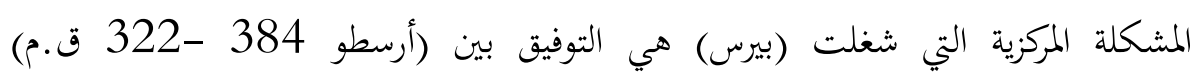

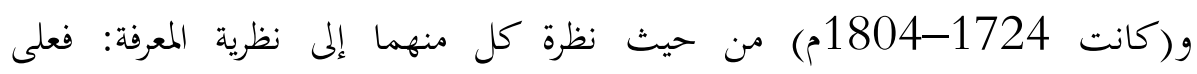
حين يذهب أرسطو إلى أن العقل يكتشف في الكون نظاما كان موجوداً من قبل، يقلب كانت هذا الوضع الأرسطي فيزعم أن النظام في معرفتنا يأتي من العقل وحده وهنا يتقدم

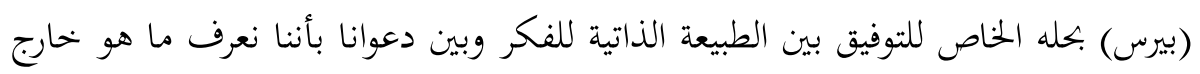
أفكارنا"(49) وبالنظر إلى رؤية (أرسطو) في المعرفة Knowledge فإنه على الرغم من ئن

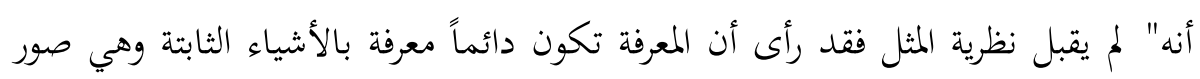

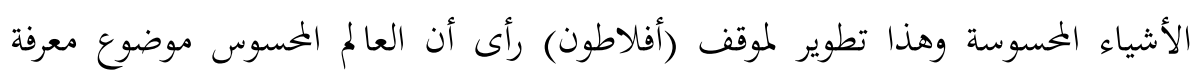

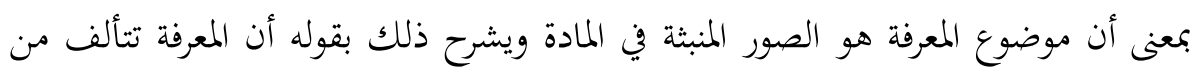

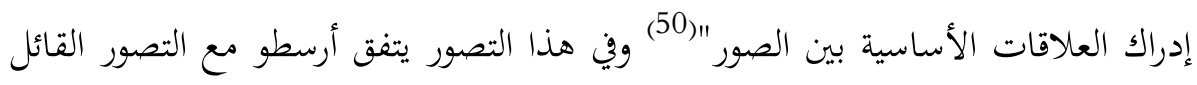
" مصدر الإحساسات هو العالم الخارجي، هو المادة، هو الوسط المادي، الظواهر والأشياء 
المكونة له. إن الإحساسات هي الإساس الذي تقوم عليه جميع ظواهر الوعي ولاوجود لهذا الوعي بلا تلك الإحساسات إن الإحساسات والإدراكات عبارة عن إنعكاسات للأشياء

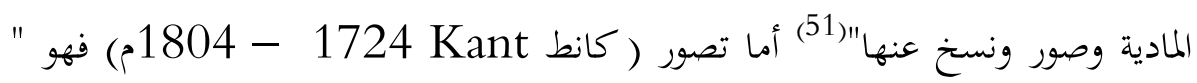
المعرفة تبدأ بالإنطباعات الحسية كما رأى التجريبيون ، لكنه اختلف عن التهن التجريبين في قوله إن هذه الانطباعات لا تكفي لحدوث الإدراك الحسي، بل يجب أن يضاف إليها أفكار

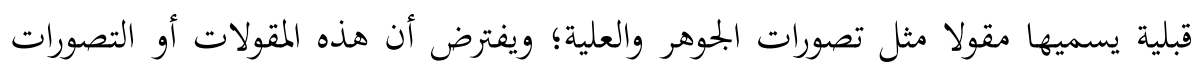

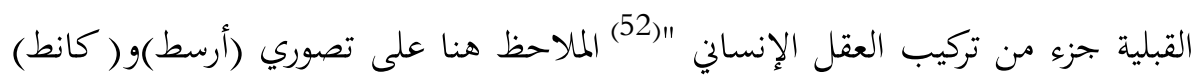

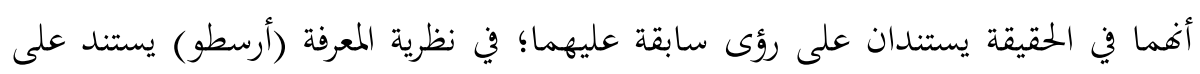

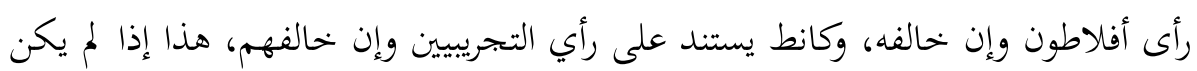
من الصواب القول بأن الرأيين تطوير لما سبقهم! هذه المحاولة لتقديم حل أوجددت القاعدة

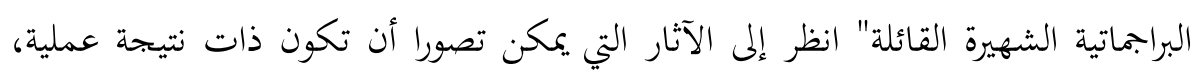
والتي نتصور أها آثار تترتب على الشيء الذي هو موضوع إدراكنا، فعندئذ يكون إدراكنا

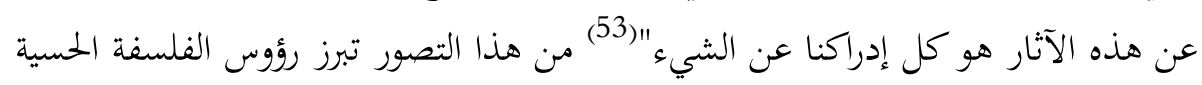

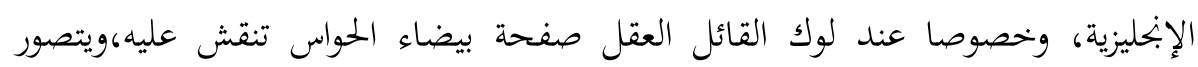

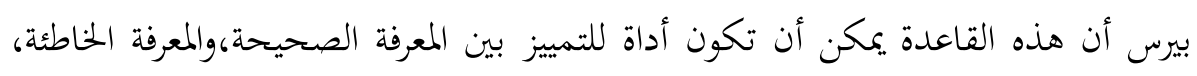
الصح والخطأ مفاهيم من طبيعة البحث العلمي في العلوم الطبيعية، التي تقام على إجابات

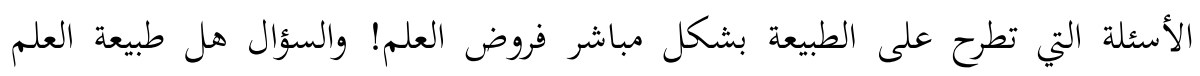

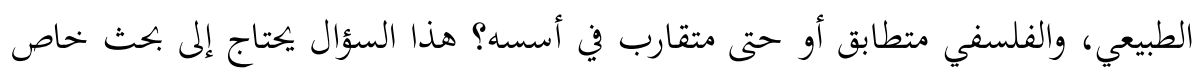
به لقيمته وتشعبه.

تشير المراجع الفلسفية إلى أن نشأة الفلسفة البراجماتية كانت" في النادي الميتافيزيقي الأمريكي بين عامي 1872 - 1874 م وكان بيرس قد تقدم إلى هذا النادي ببحث نشر بعد ذلك في مقالين منفصلين أحدهما ظهر في عام 1877 م تحت عنوان تثبيت الإسعتقاد The Fixation of Belief والآخر بعنوان كيف نوضح أفكارنا 
How to make our ideas clear في هذا البحث أن يجيب على هذه الأسئلة: متى يكون للفكرة معنى؟ ومتى تكون العبارة

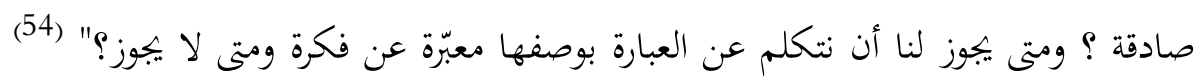
هذه الأسئلة لم تتبلوري سنتين، ولكنها نتاج لجهد طويل • كان من أهم نتائجه رفض (بيرس) للابحاه المثالي، ولاسيما المثالية الهيجلية ويقرب بعض البحاث ذلك بكاثل بسنة 1870

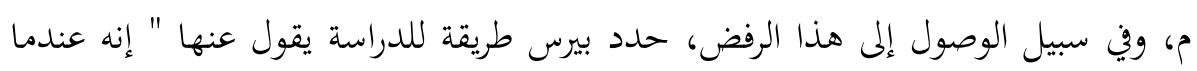

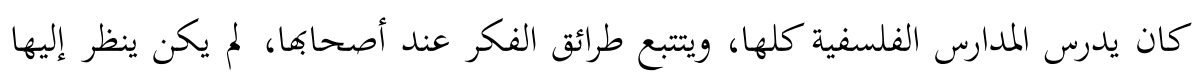
من وجهة نظر الفيلسوف اللاهوتي، الذي يتناول مادته وكأنما هي معصومة من الخطأ، بل كان ينظر إليها من وجهة نظر الباحث العلمي في معمله، فيبحث عن الجمديد الذي لم يُعرف بعد. ولقد أمضى على هذا المنهج ما يزيد على ثلاثة أعوام، بمعدل ساعتين يومياً

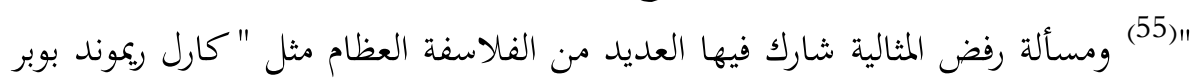
1902 K.Poper الإبحليزية الحديثة آملاً أن يصححها ـ وكان هدفه من البحث في نظرية المعرفة بيان طريقة

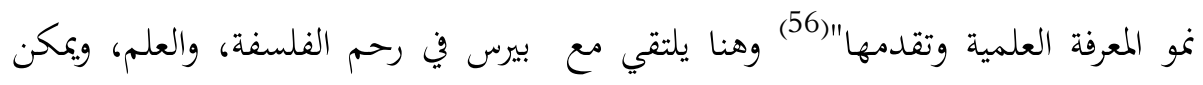

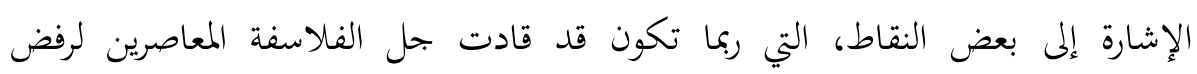
الميتافيزيقا، أوالمثالية بشكل عام ومنها " كانت تعدّ الأشياء أبدية لا تتغير؛ هي ثمرة علم

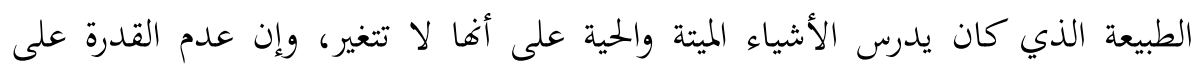

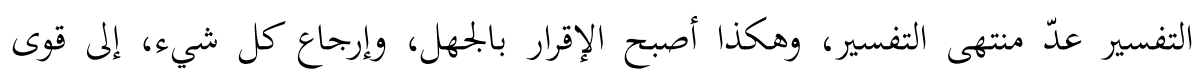

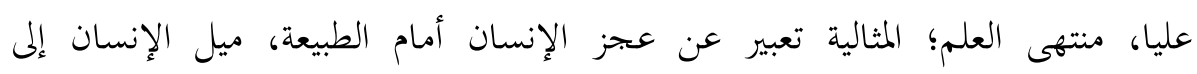

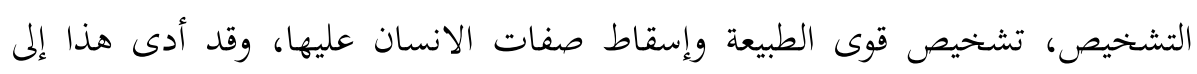

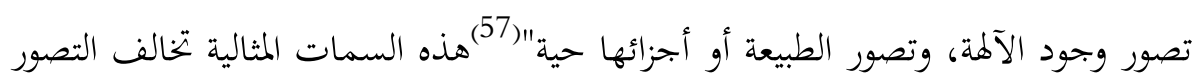

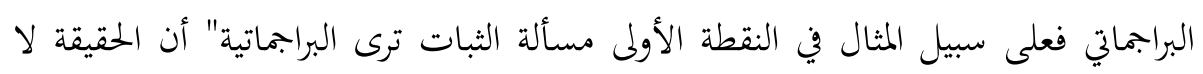
تعرف الثبات، بل هي تسيل وتخلق ألوانا من الخلق الحر، ويعجز العقل عن إدراك هذه 
الحقيقة، وتقوم كل معرفة على أساس التجربة"(58) وتشير بعض المراجع ، بخصوص التجربة،

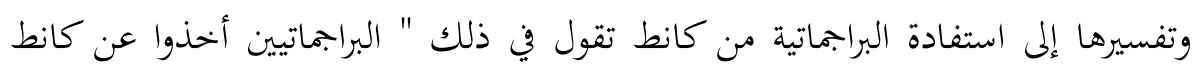
أهمية الذهن في تفسير التجربة ، كما أخذوا عنه القول بأن الأفكار لا يمكنها أن تشير إلى إلى

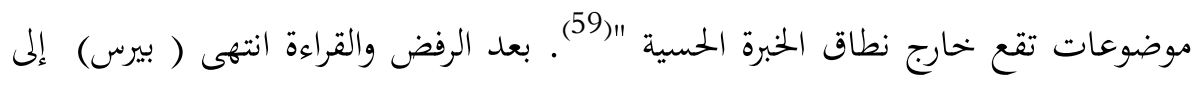
الإجابة التي ستكون عماد فلسفته، والأسئلة كلها تمحورت حول الفكرة فأجاب بأن أنساب الفكرة" الفكرة هي ما تعمله أي أن معناها يرتبط بنتائجها وآثارها العملية المترتبة عليها"(60) عند هذه الإجابة صاغ مفهوم البراجماتية. الذي أراد له أن يكون" منهجاً

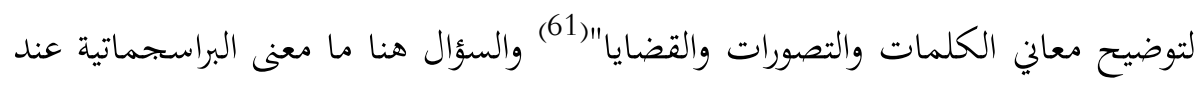
بيرس؟" وضع كلمة براجماتية Pragmatism على أفا اسم لقاعدة خاصة بتوضيح

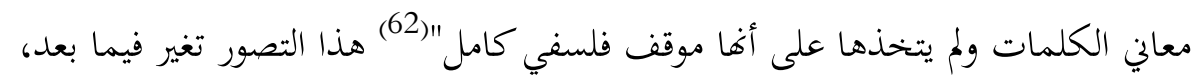
ومن أعلام البرجماتية نفسها، بحيث أصبح هذا المفهوم يعني اسماً لأي موقف يؤكد أهمية

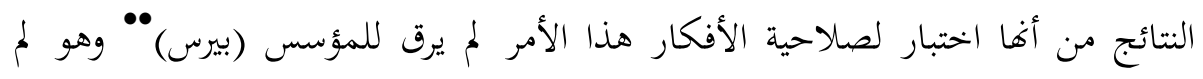

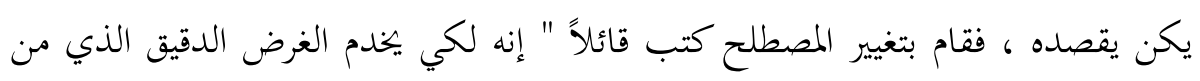
أجله صاغ مصطلحه الأصلي، فهو يود أن يعلن مولد كلمة أخرى هي البرجماطيقية Pragmaticism الدلالة المقصودة، من طرف المؤسس ولقد أوجز بيرس فلسفته فقال" إن فلسفتي يمكن

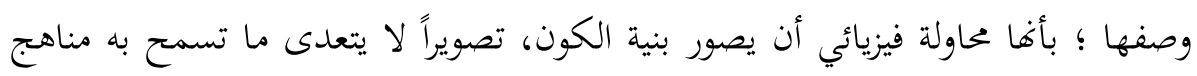

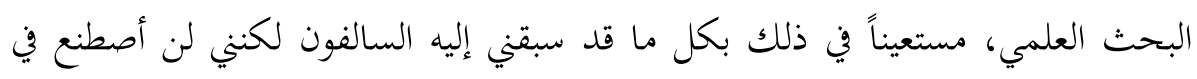
هذا طرائق الميتافيزيقيين في الإستنباط الذي يقيمونه على فروض يصفوها بالصواب القطعي القيني

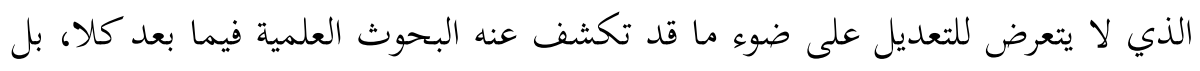

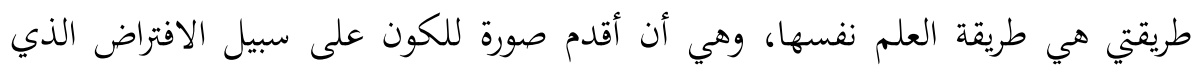
ينتظر الإثبات على أساس ما قد يتكشف لنا من حقائق، ولذلك فهو يتميز أول ما يتميز

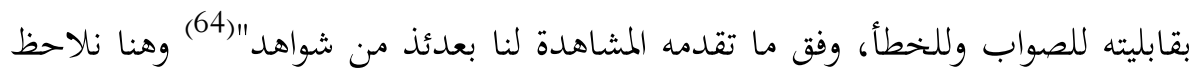


أن فلسفة بيرس أعتمدت على العمل المشترك، والمتتابع، ففي هذه الفلسفة قد يصل إلى النتيجة ليس الفيلسوف الذي طرح السؤال، ولكن شخص آخر فهي ليست بالإنتاج

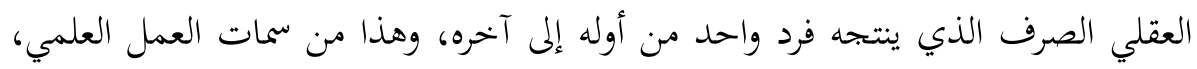

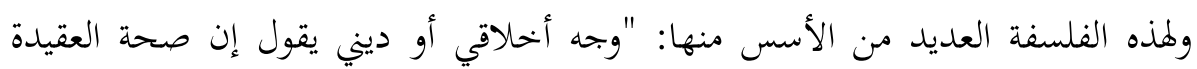
تابعة للإرتياح الذي تولده في الضمير، ووجه علمي يقول إن صحة القانون تابعة للتطبيقات

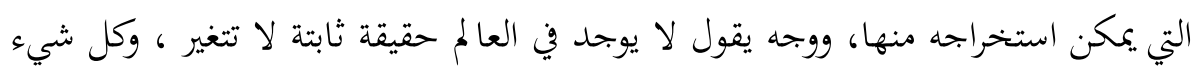

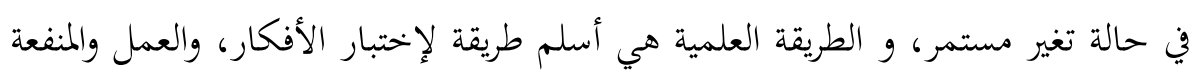

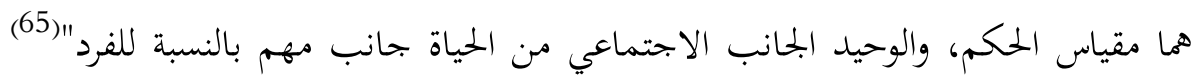

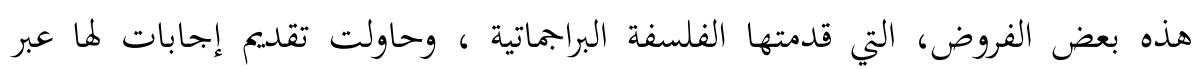
مسارها البحثي . ولهذه الفلسفة عدة أُسس ومبادئ منها : تتمثل مبادئ الفلسفة إنسية

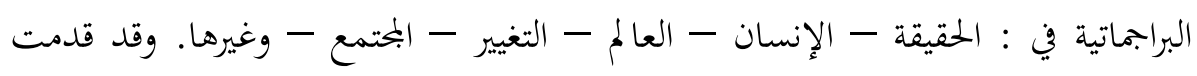
هذه الفلسفة خصوصا في المرحلة الأولى مع بيرس عديد التصورات من أجل فهمها بصورة جلية منها أن فلسفة بيرس تقوم على بحموعة من التصورات Concepts" منها:"

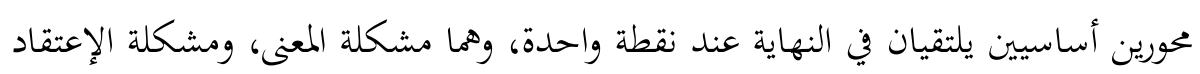

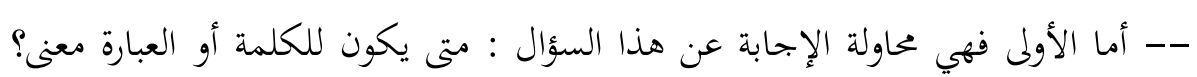
وأما الثانية فهي تجيب عن هذا السؤال: إن كان لديّ إعتقاد معين بأن هنالك في العالم المان

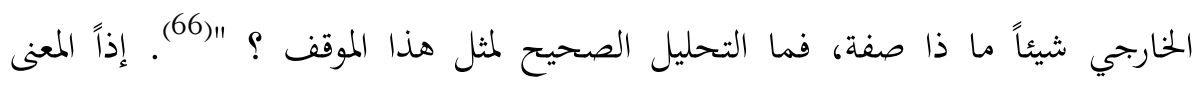
والإعتقاد هما المحاور الجوهرية في الفلسفة البراجماتية، وتعرف القواميس الفلسفية الاعتقاد بأنه" الاعتقاد في المشهور هو الحكم الذهني الجازم، القابل للتشكيك، بخلاف اليقين.

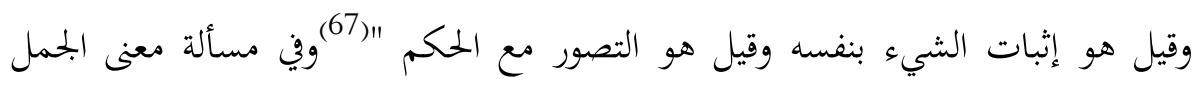
والعبارات في اللغة خصوصاً في البناء الفلسفي فإن هنالك العديد من التبات التصورات التي ناقشت هذه الإسشكالية منها التصور الوضعي المنطقي الذي يقول" إن ما يمكن قوله من

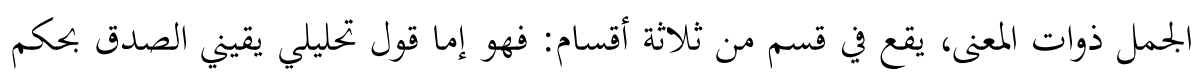


كونه تحليلاً، أي أن الشطر الثاني من الجملة يكرر شطرها الأول بألفاظ مترادفة مع ألفاظ الشطر الأول، كقولنا: إن العم هو شقيق الوالد؛ أو هو قول متناقض مقطوع ببطلانه لأن

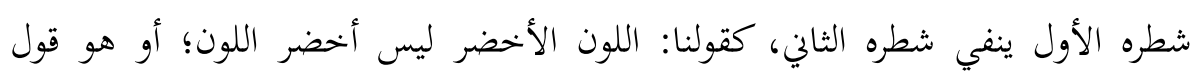

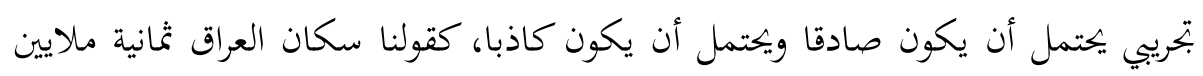
نسمة؛ هذه هي الاقسام الثلاثة للجمل ذوات المعنى سواء كانت صادقة المعنى أم باطلة المعنى "(68) وهناك تصور آخر ينص على أن المعنى هو" أن مفهوم المعنى في نظريتنا العامة على نوعين :

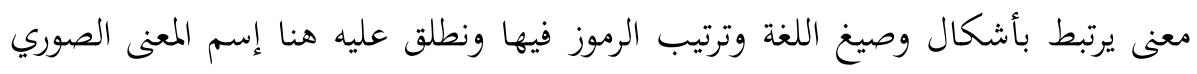

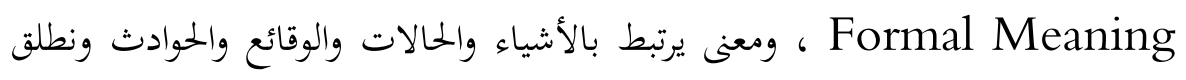

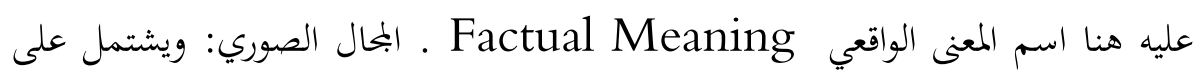
المتواليات والصيغ والأشكال شريطة أن يكون للمتواليات والصيغ وغيرها معاني صورية، وإلا

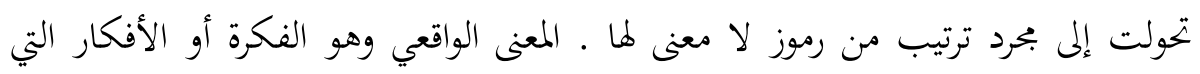

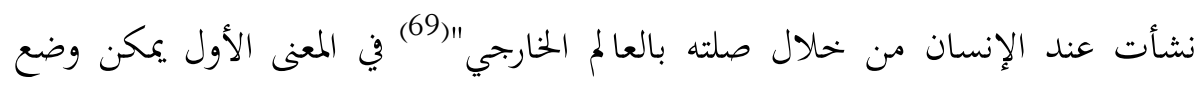
الرياضيات، والمنطق حسب تصور ( بيرس ) لأنه يرى فيهما اليقين، وبالمعنى الثاني تدخل

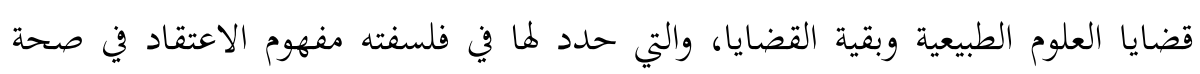

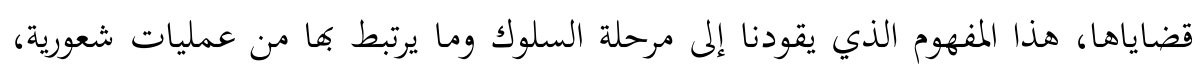

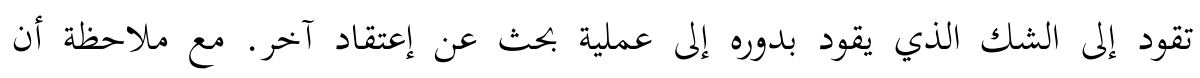

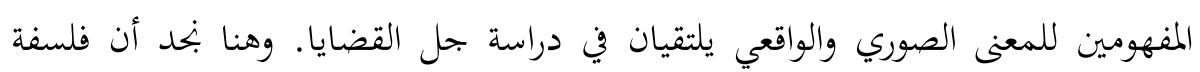
بيرس يلتقي فيها: الاعتقاد والمعنى؛ والصوري والواقعي في اللغة. كما تحاول ايجاد تكافؤ بين

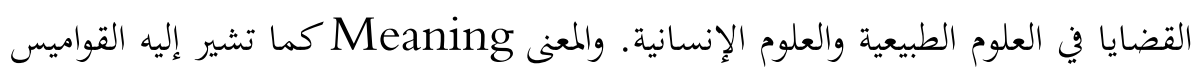

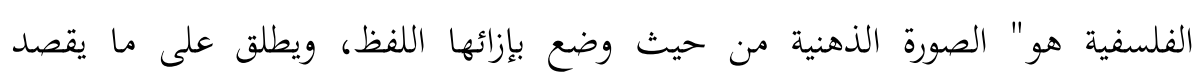
بالشيء، أو على ما يدل عليه القول، أو الرمز أو الإشار "(70) ويحدد بيرس قاعدة للتحقق بازئ

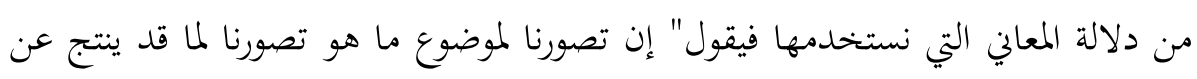


هذا الموضوع من آثار عملية لا أكثر. وهذا يعني أن علامة الحقيقة أو معيارها العمل المنتج

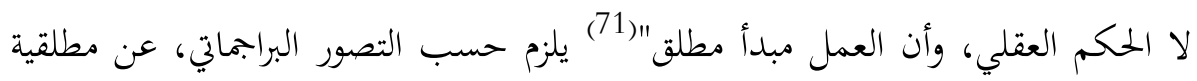
العمل حريته في كل الإتحاهات؛ الأمر الذي يترتب عليه مرونة العالم بحيث نستطيع التأثير فيه وفق فروضنا وتصوراتنا. وتعد الفكرة إضافة إلى المعنى والاعتقاد من أسس الفلسفة

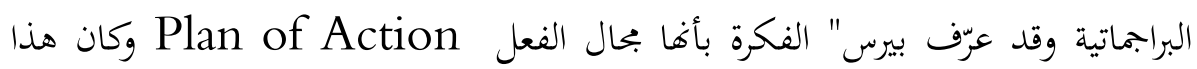

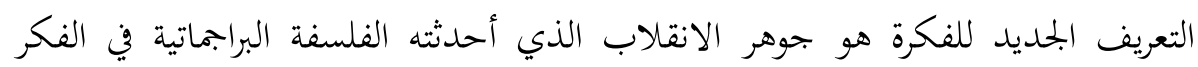

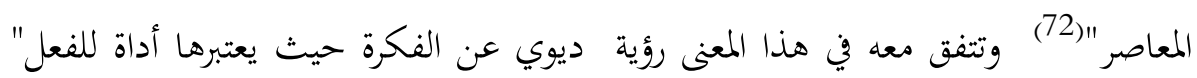

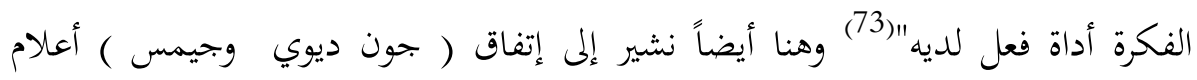

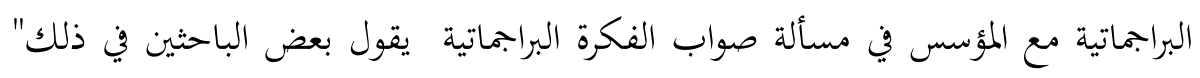

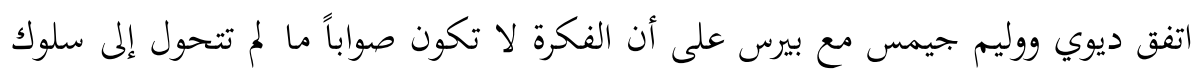
ناجح في حياة الإنسان، فالحق هو النتائج الموفقة التي تترتب على إعتناقه وجاهر ديوي

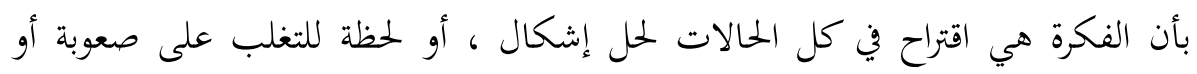
مشروع للتخلص من مأزق، فهي في كل الحالات أداة للعمل ، وبمقدار بنحاحها في توجيه سلوك الإنسان بمقدار حظها من الصواب"(74) والدارس لفلسفة بيرس يلاحظ إصراره "

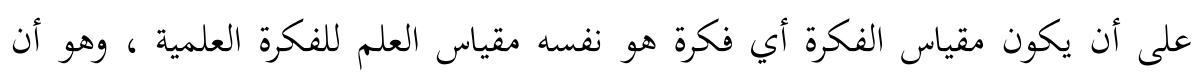

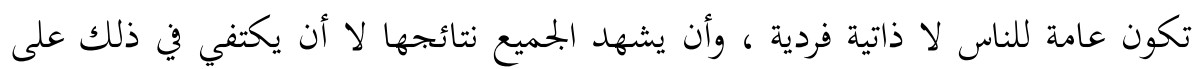

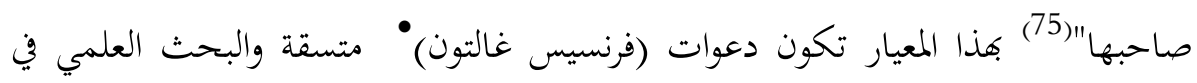
نطاق المعرفة التي يدعو لما بيرس · وفي هذا السياق نلاحظ إتفاق (كليرنس لويس) مع (بيرس)" في ضرورة أن يكون للتصورات مضامين عملية، هدفها من ذلك هو إمكانية

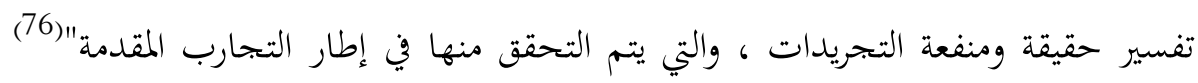

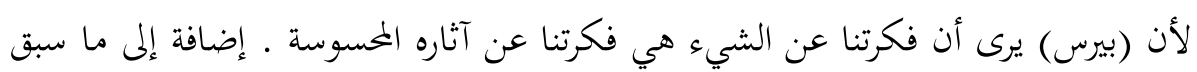
من أسس يأتي المنهج؛ والمنهج الذي يراه (بيرس) هو منهج العلوم الطبيعية،فالتفكير عنده يجب أن يسير على نفس الأساس، الذي يسير وفقاً له في معامل الطبيعة وري أذهان 
العلماء، الذين يقومون بتجاربهم في هذه المعامل، والمعرفة كائنة ما كانت لا تستحق هذا الاسم إلا إذا كانت لما نتائج عملية، يمكن لكل إنسان أن يشاهدها؛ ويرى بعض الباحثين

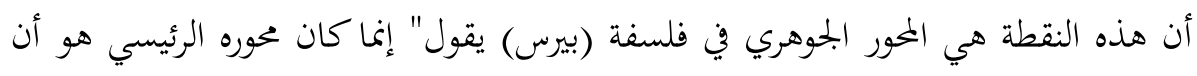
يجعل كل تفكير يجري على أساس ما يجري في معامل العلوم الطبيعية؛ (والنتائج العملية) هي مبدأ نظريته في المعرفة"(77) هذا الموقف من (بيرس) يكاد يتطابق مع موقف البراجماتي

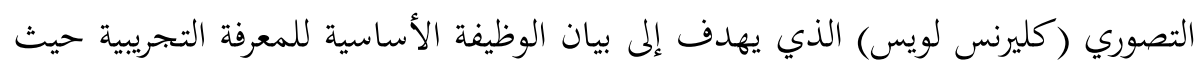
"يؤكد أن وظيفتها هي الإنتقال من الحاضر إلى المستقبل ، الذي نستهدفه فالمعرفة تعني فهم

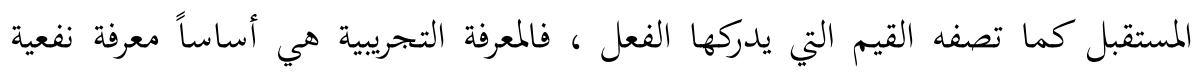

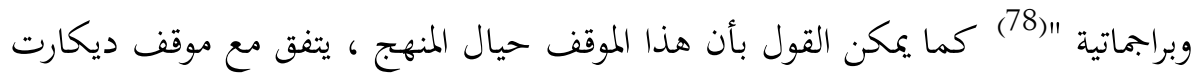

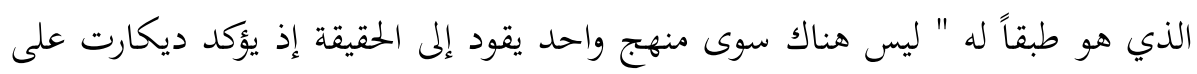

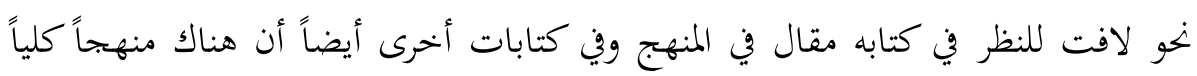
واحداً فقط لجميع موضوعات المعرفة الممكنة"؛ (79) وهنا نلاحظ إصرار بيرس على النتائج وإعتبار فلسفته فلسفة مضمون، أكثر من كوها فلسفة صورة منطقية، وهو بهذا كأنه يعلن أن منطق فلسفته يخالف تصورأرسطو والوضعية المنطقية التي تقول عنها بعض المراجع "كان

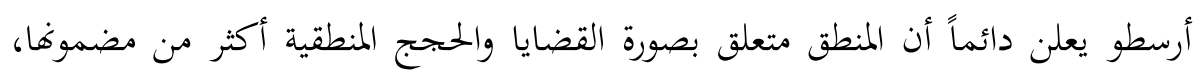

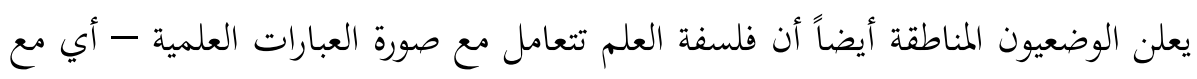

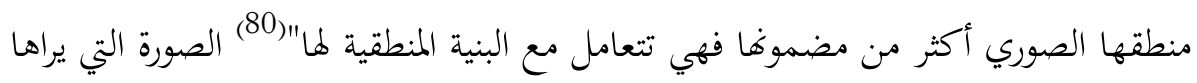

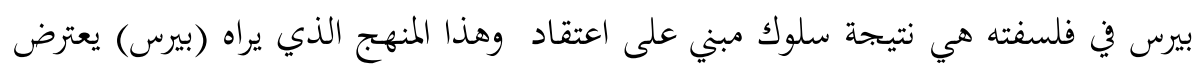
عليه فلاسفة الفنومنولوجيا وبعض فلاسفة آخرين؛ مبررين ذلك بعدم قدرته على النفاد إلى لي لئي جوانية الظاهرة الإنسانية ، النص التالي يوضح ذلك "الوجود الإنساني أو الظاهرة الإنسانية على كافة مستوياتما تتعين بالوعي، الذي يقصد إلى المعنى، ويهدف إلى القيمة من خلال

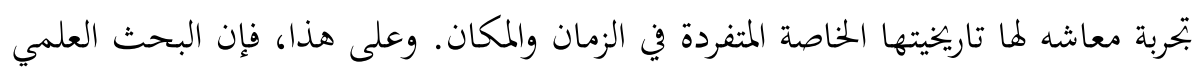

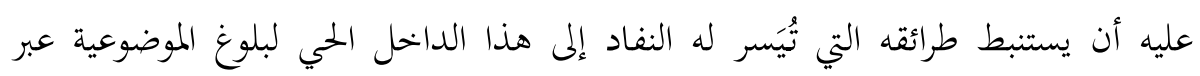


تفهم Verestehen مباشر يمضي بالباحث إلى الأساس الصلب الذي يقيم عليه

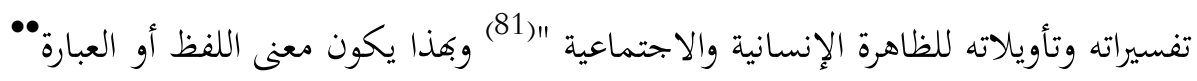

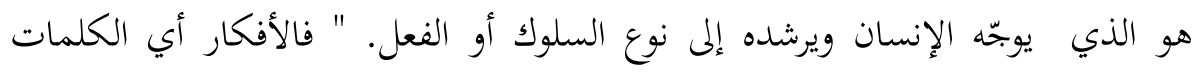

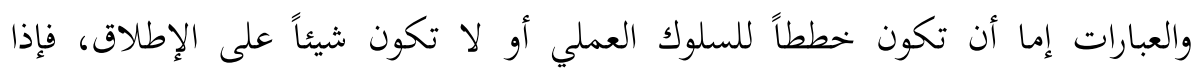

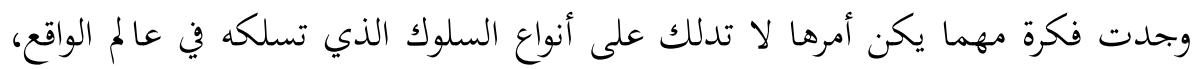

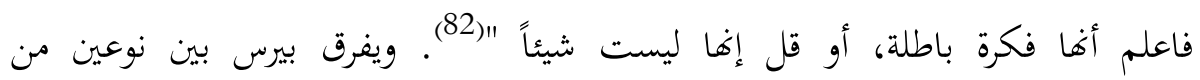
المشكلات: المشكلات الحقيقية ؛ تكون كذلك لو أمكن أن يخضع حلها للتجارب العلمية

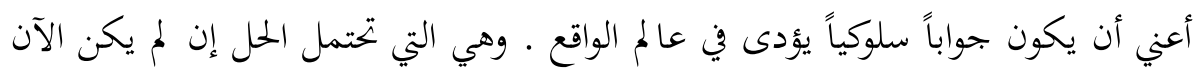

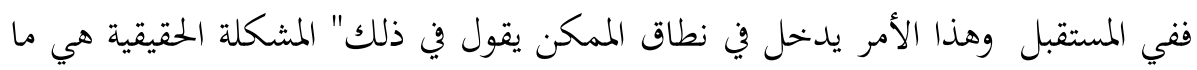

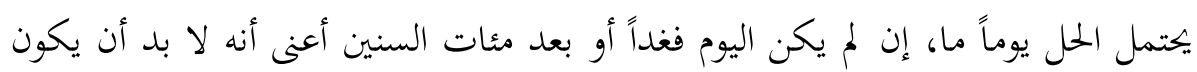

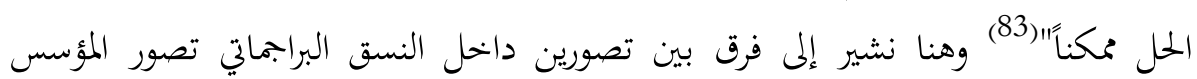

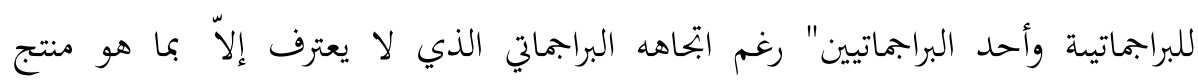

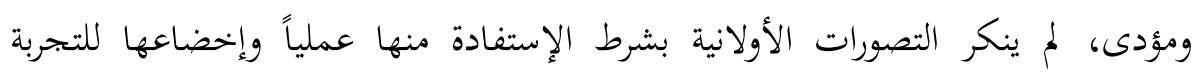
ومطابقتها للواقع؛ وبناء على ذلك يمكن القول بأن لويس يؤمن بالنظرية البراجماتية الخاصة

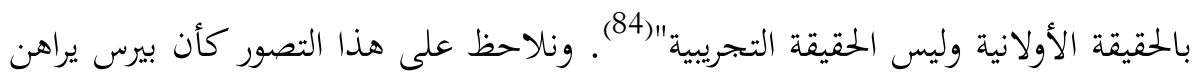
على قدرة العلم وإمكانية تطوره كما في علوم الفلك الآن ودراسة البحرات فتعليق القضايا الحقيقية بهذه الصورة كان من الممكن أن يؤدي إلي القول بالأدري ولكني أحسب أن

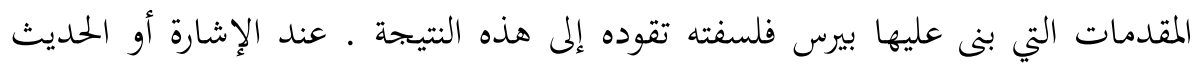
عن التجارب في البحوث العلمية دائماً يتبادر إلى الذهن التجارب المقامة على مواد كما

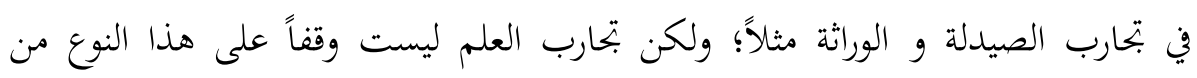

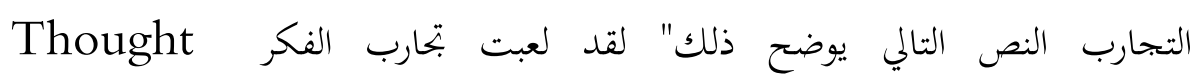
Experiments، ولأكثر من مرة، دوراً نقدياً هاماً في تطور العلم الفيزيائي. ويجذر لهُ بالمؤرخ على أقل تقدير، أن يتعرف عليها بوصفها أداة فعالة في بعض الأحيان لزيادة فهم 
الإنسان للطبيعة، فهي تتعامل غالباً مع مواقف لم تفحص في المعمل كما هو الحال مع قطار آينشتين المنطلق بسرعة الضوء من كلا حافتيه وهي تفترض، في بعض الاحيان، وكما

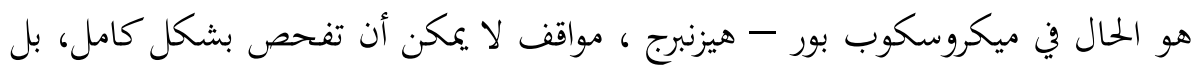

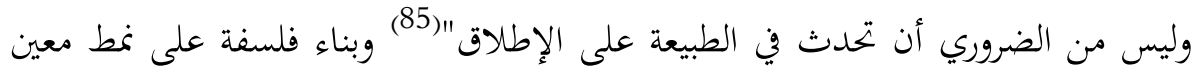
من بحارب العلم يواجه صعوبة كبيرة ، وهنا يأتي جواب آخر يقول: بما أن تصور بيرس

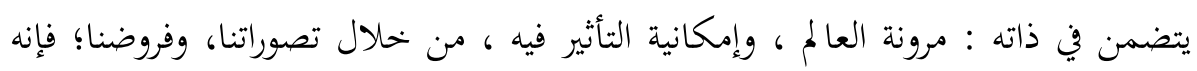

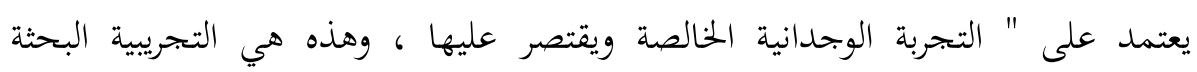

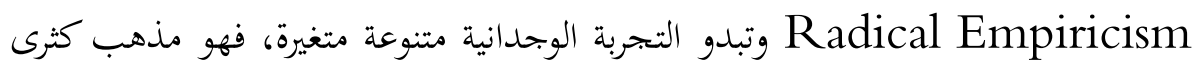

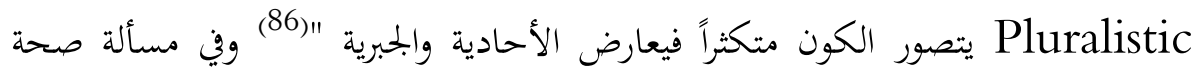
القضية Proposition في الفلسفة البراجماتية فإن هناك تصور يقسم هذه الفلسفة إلى تيارين هما : التيار المتشدد ، التيار المعتدل، يقول عنهما" على حين أن التيار الأكثر تشدداً يعلن أن القضية الصحيحة هي التي تؤدي إلى بناح فردي، فإن التيار الأكثر اعتدالاً يرى

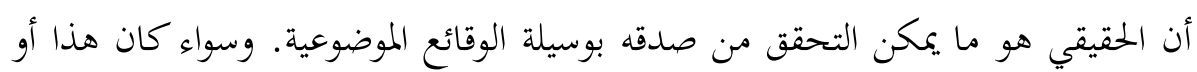

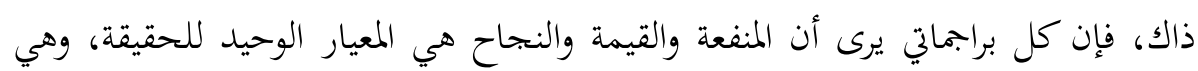

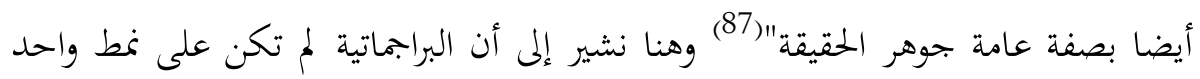

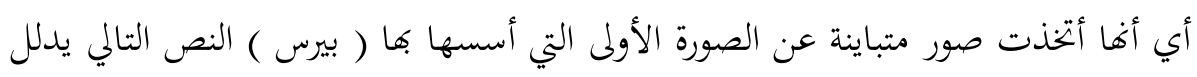

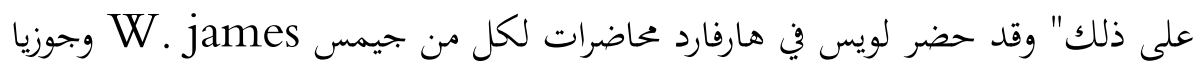
رويس Josiah Royce وكان متأثراً بما كان لدى رويس من قوة حجة وإقناع خارق لا يعرف التعب، حيث يقول عنه من هنا أصبح رويس وظل حتى الآن الصورة المثلى لما يجب

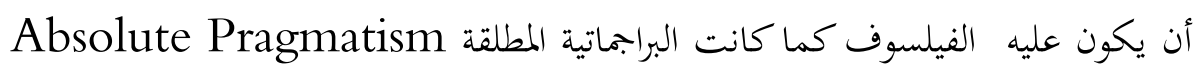

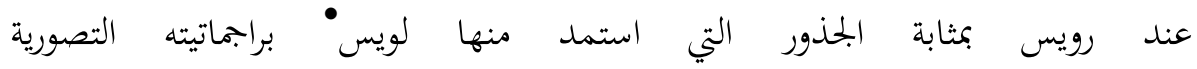
Conceptualistic Pragmatism المشكلات لا يمكن حله لأنه : يحتوي على ألفاظ أو عبارات خالية من المعني أومن الممكن 
القول بأن موضوعها لا يدخل في حدود الخبرة الإنسانية فعلاً أو إمكانا؛ والأمر الذي يجعل حل هذه المشكلات مستحيل حسب تصور بيرس" لأهما ليست بمشكلات حقيقية، لأهما

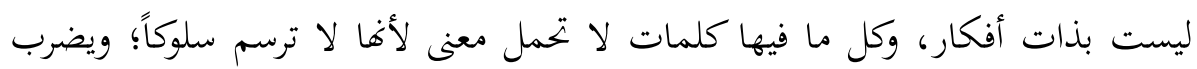

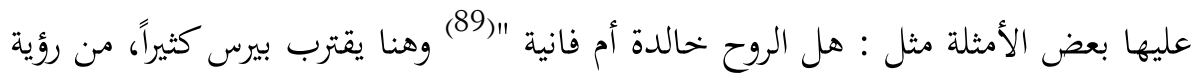

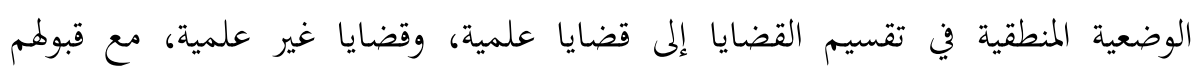
لقضايا المنطق، والرياضيات بإعتبارها قضايا علمية، دون التأكيد على اختبارها وهي تعادل قضايا المنطق والرياضيات، التي يرى إمكانية الوصول فيها إلى يقين بعكس القضايا

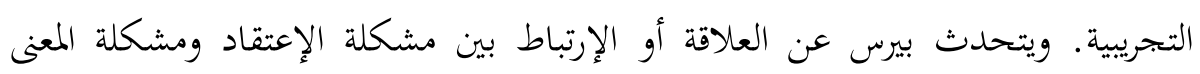

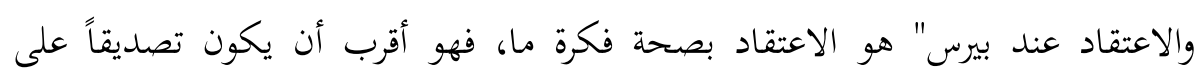

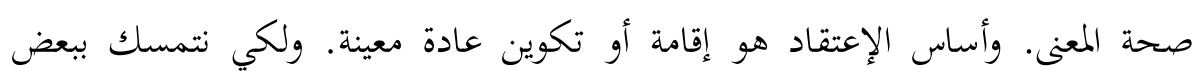

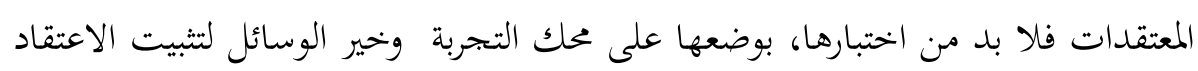

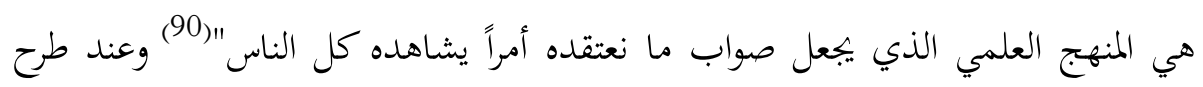

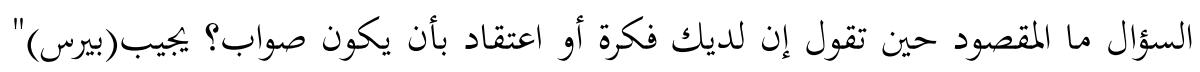

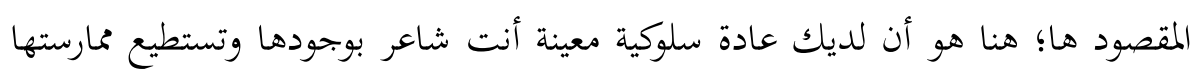
إزاء هذا الذي تقول عنه إنه صواب ـ فالفكرة التي تظن بها الصواب تأويلها هو ما أنت

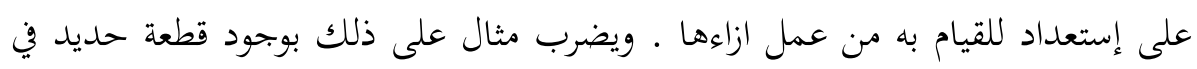

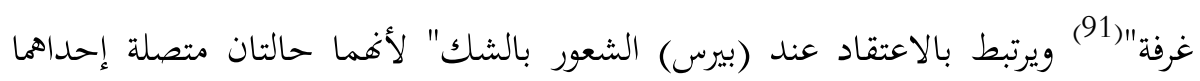

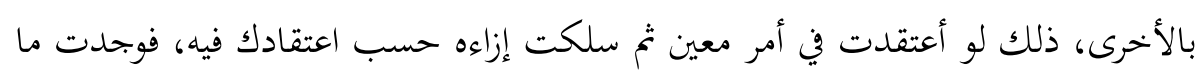
يعطل هذا السلوك أو يغيره على أي وجه من الوجوه شككت في إعتقادك الأول الذي كان

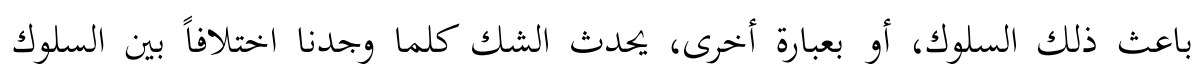
الواقع والسلوك المتوقع ؛ ويعود إلى ثقل الحديد والسلوك نهوه في الحالة الإيجابية وفي الحالة السلبية "(92) في الحالة الإيبابية يستمر الاعتقاد وفي الحالة السلبية يتغير الاعتقاد الأمر الحرد الذي يترتب عليه تغير السلوك في الحالة الثانية؛ كذلك يتولد عن الحالة السلبية الشعور 
بالدهشة ثم يأخذك الشك في صواب ماكنت تعتقد فيه فيتغير الإعتقاد ـ من هذه العلاقة

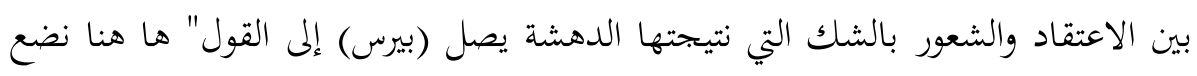

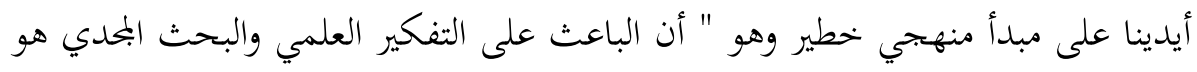

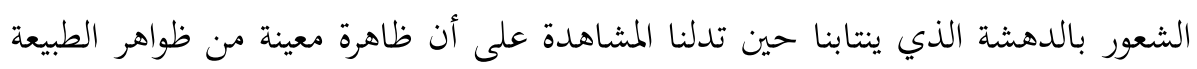
لم بحر معنا في خبراتنا على النحو الذي توقعناه لما، فعندئذ فقط نشك فيما كنا قد اعتقد

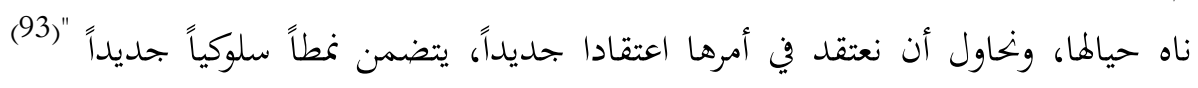
وعلى هذا يمكن تصنيف الشك عند (بيرس) إلى: شك حقيقي وهو الذي يستوجب تغير

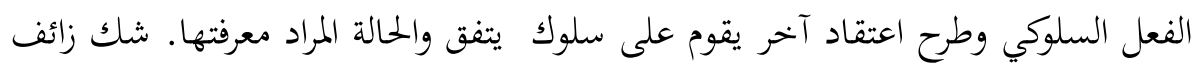
وهو الذي لا يصل إلى مرحلة تغيير الإسسعتقاد ولكنه يثبته والسلوك المرتبط به. والسؤال المهم الذي يطرحه عديد الباحثين ما الغاية من نظرية فيلسوف البراجماتية في الاعتقاد

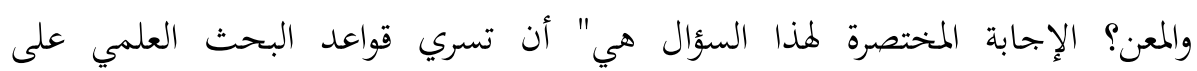
الفلسفة"(94). وهنا يكون السئال في تصور (بيرس) لماذا يسمح الفيلسوف لنفسه أن يقول قولاً لا يمكن أن تترتب عليه نتيجة عملية ومع ذلك يحسب أن لقوله معنى؟ أين يكون المعنى إذاً ؟ " نعم ، إنه لا معنى لقول، ولا أساس لإعتقاد إلا إذا كان ذلك المعنى أو هذا لتها

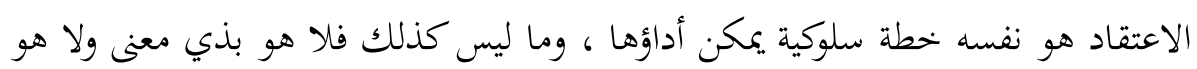
بالفكرة التي يجوز أن تكون موضع إعتقاد هذا هو لباب المذهب البراجماتي عند البدائ

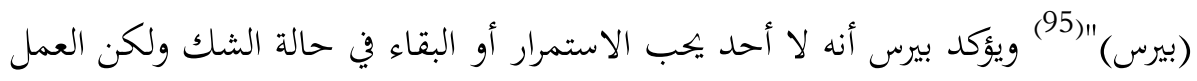
دائم من أجل الوصول إلى حالة الإعتقاد ورغبة الإنتقال من الشك إلى الاعتقاد يسميها

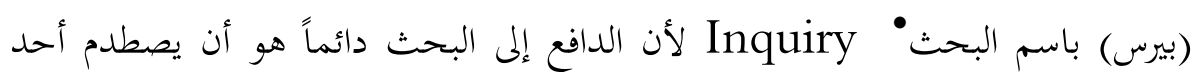

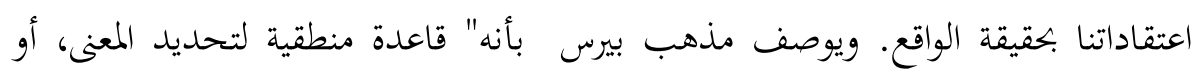

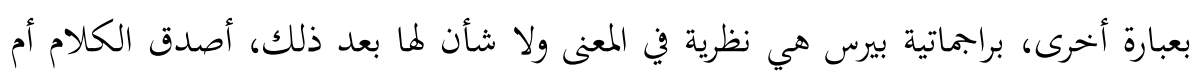

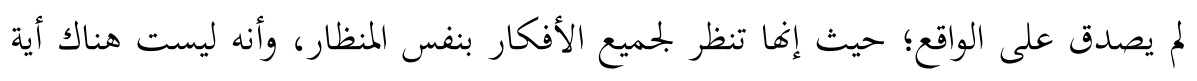

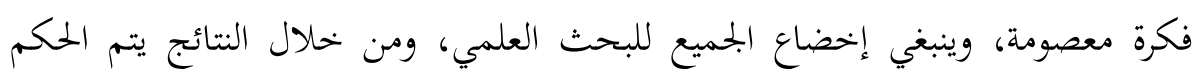


بصحة تلك الفكرة من عدمها، مع ملاحظة أن النتائج قد لا تتم على يد نفس الفيلسوف وإبما قد تتم بعده بزمن "(96)

مقولات Categories" بيرس:" أراد بيرس أن يضع مقولات جديدة تعبّر عن

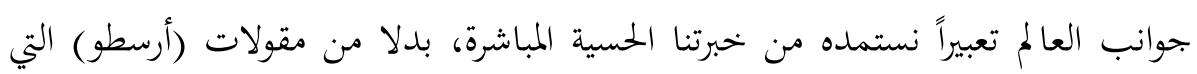

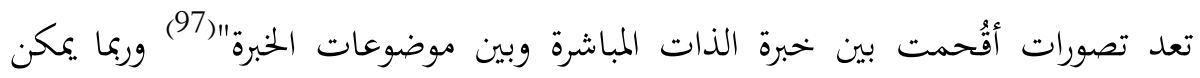
القول أن العملية التي تبناها بيرس للتوفيق بين تصور(أرسطو) و(كانط) كانت هي العامل الحاسم في طرح هذه المقولات لأن مقولات أرسطو لا تستجيب للعملية التوفيقية التي لئي أرادها بيرس. وهذه المقولات هي: مقولة الرتبة الأولى: وهي المظهر التلقائي للأشياء، وهي

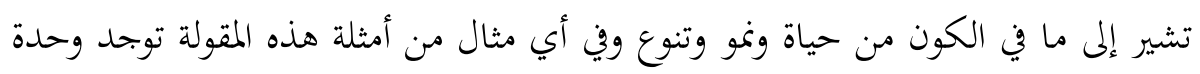

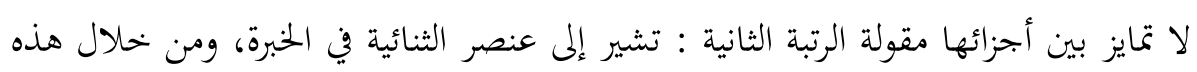
المقولة يؤكد بيرس قيام الوجود الخارجي مقولة الرتبة الثالثة ويطلق بيرس على هذه المقولة

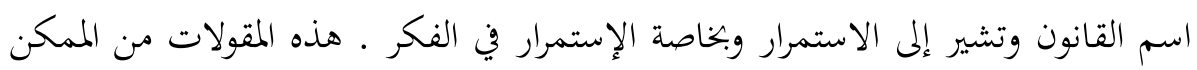

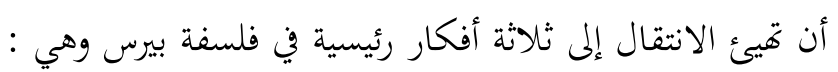

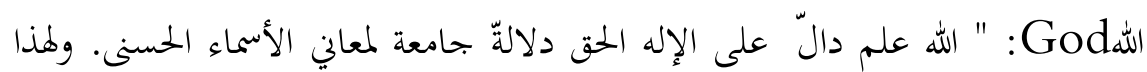
الاسم عند الفلاسفة عدة معان منها: المعنى الإجتماعي، وهو إطلاق لفظ الاله على الهى

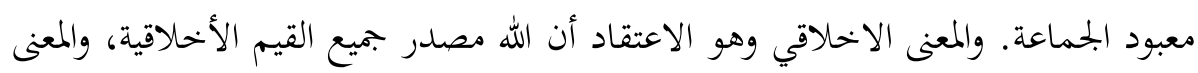

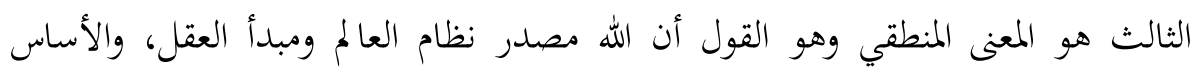
الذي يضمن مطابقة الحقائق التي في الأذهان للأشياء الموجودة في الأعيان والمعنى الرابع هو

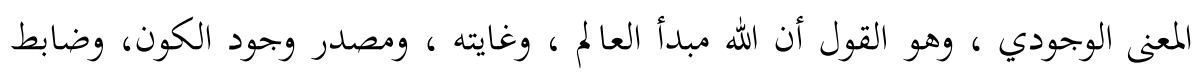

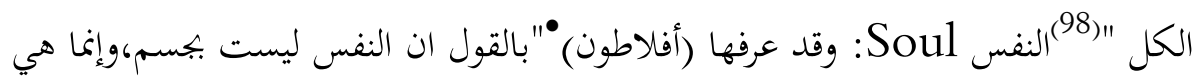
جوهر بسيط محرك للبدن. والنفس مبدأ الحياة أو مبدأ الفكر، أو مبدأ الحياة والفكر معاً. وهي حقيقة متميزة عن البدن، وإن كانت متصلة به"(99). وفي تصور أرسطو للنفس يقول بأها " طاقة الجسد، ومن هنا فهي الحقيقة التامة للكائن الحيّ "(100) 
الخلود Immortality عن هذا المفهوم تقول بعض المراجع الفلسفية " إن البحادلة الأولى

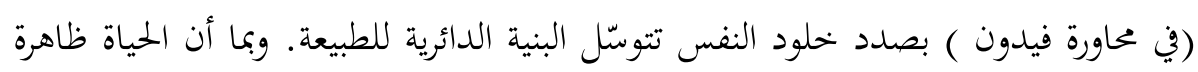

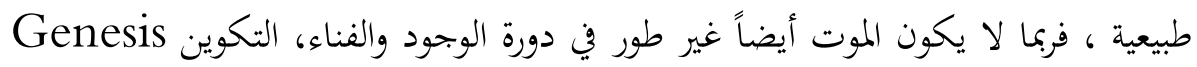
والانحلال Phthora. إن مجرى المحادلة الذي يبني نفسه على السمة الدورية للطبيعة

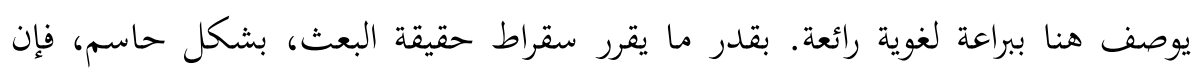

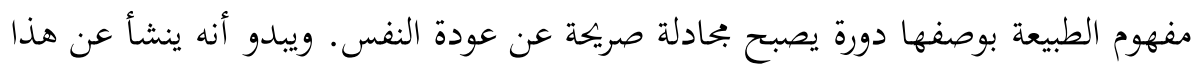

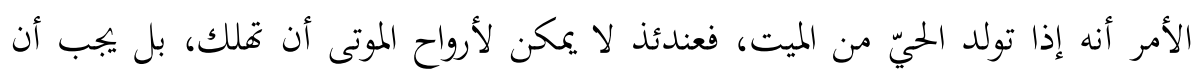

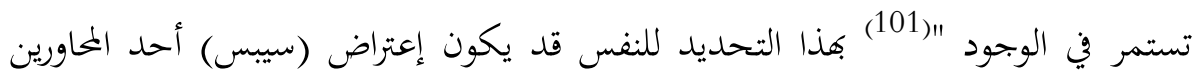

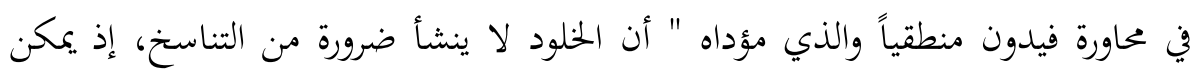
للنفس ، بارتحالها عبر الأجساد المختلفة، أن تستهلك نفسها أكثر فأكثر حتى تنحلَ أخيراً في الجسد الأخير. ومن دون ريب، يعكس هذا الاعتراض أحد اكتشافات علم الأحياء في ذلك الوقت "(102) والخلود في تعريف القاموس الفلسفي" الخلود هو الدوام والبقاء تقول خلد في النعيم دام وبقى، ومنه خلود النفس، أي بقاؤها بعد الموت ودار الخلود الجنة.

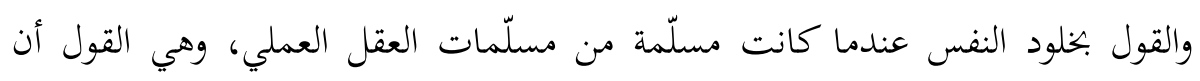

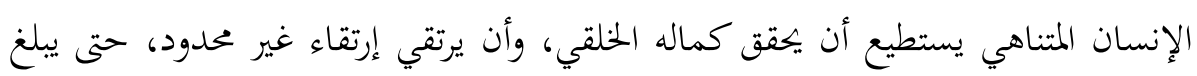

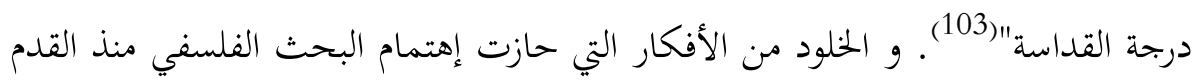
يقول بعض الباحثين في ذلك" إن موضوعة محاورة فيدون التي تطوّرت عبر وصف اليوم

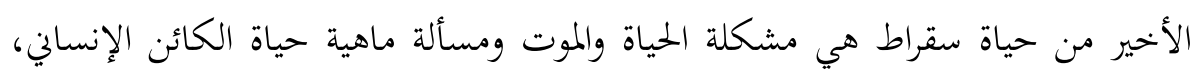

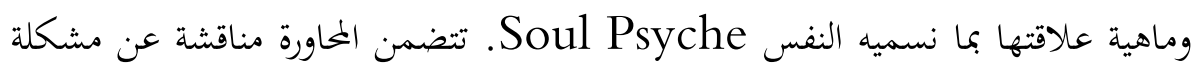
النفس والاعتقاد بالخلود الذي علمتنا إياه الأديان. فهل بمستطاع عقلنا أن يجد أساساً

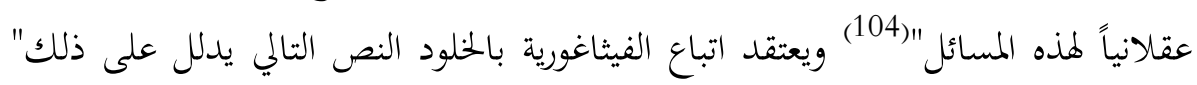
كانوا يعتقدون بخلود النفس وبانتشار الأرواح الحارسة في الهواء ، وبأن هذه الأرواح تزور

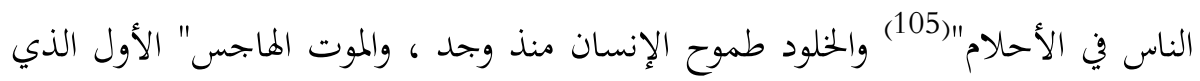


طارده في كل خطواته، فراح يبحث عن الخلود هرباً منه ، بيد أن جلجامش الحائز على نبتة

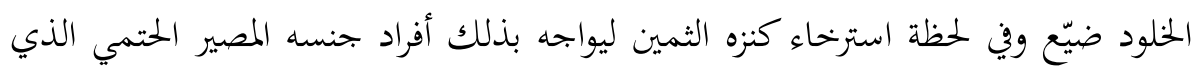

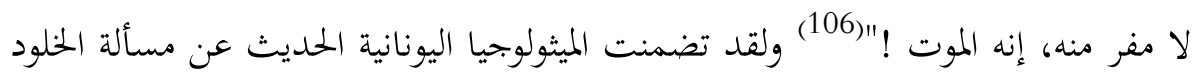
أو الرغبة في الخلود النص التالي يدلل على ذلك " في الأورفية كانت ديمتر في الوسيس إنه

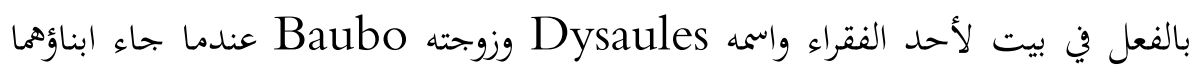
Euboules Triptoiemus جعل الولد الرضيع لمضيفيها خالداً بدهنه بنوع من الدهان الإلهي وطرحه في النار "(107) وهنا نشير وفي مسألة الخلود، إلى أنه بعد أن تناول (غادامير) محاورة فيدون بالتحليل

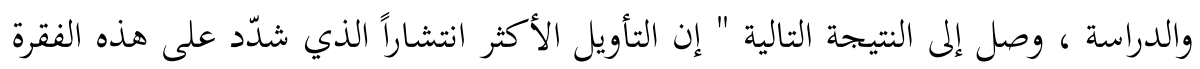

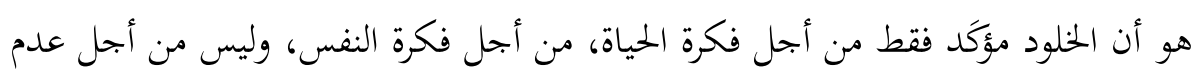

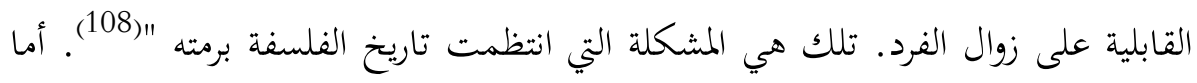

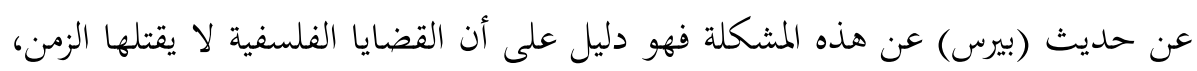
وقد لا نكون مبالغين إذا قلنا ولا يستوفيها البحث، فمن محاورة فيدون ومن دهان ديكتر،

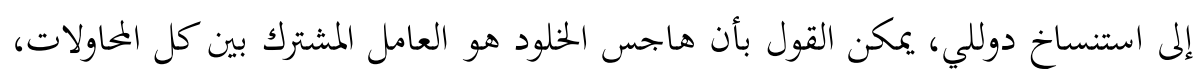

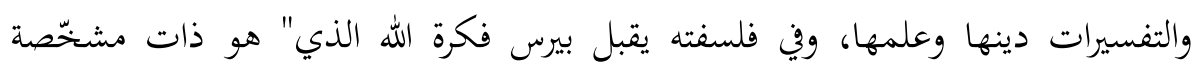

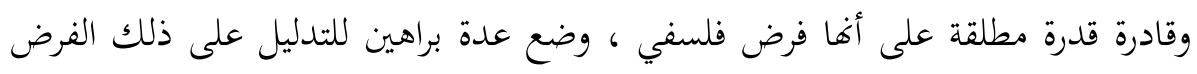
منها : ذلك التنوع، والتلقائية التي بتح أعلى تعبير عنها في الشخصية الإنسانية يساعدنا على أن نرى تلقائية لا متناهية أو رتبة أولى. وقال بإله يستطيع الإنسان أن يدخل فيل معهد في

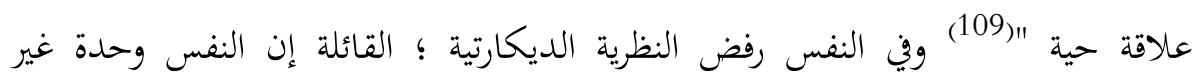
منقسمة وذات شفافية، وأصر على صلات الذات بغيرها من الناس والكون؛ ورفض بيرس

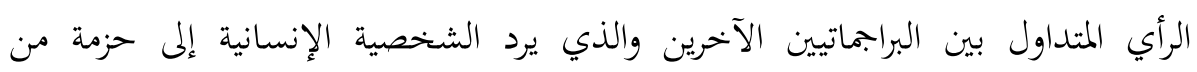

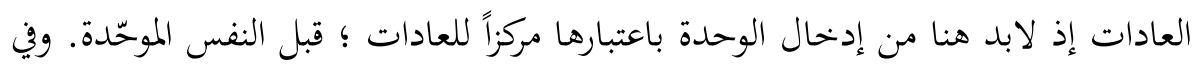

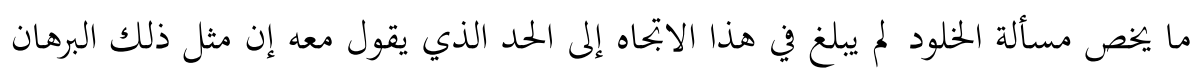


قاطع "(110) ملاحظات على فلسفة بيرس: بعد هذا الاستعراض لفلسفة مؤسس البراجماتية نقدم بعض الملاحظات على تصوره العام منها: تعتبر فلسفة (بيرس) من ضمن الاتحاهات

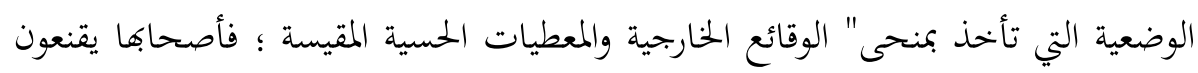
بإحالة القضية بأسرها إلى النموذج القياسي Paradigm للعلم الطبيعي؛ حيث ينكرون الفروق بين العلوم الإنسانية والطبيعية، وحسب الباحث أن يلتزم بمزاولة المنهج المتفق عليه

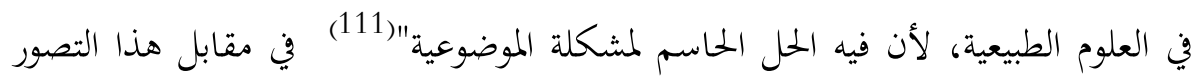
هناك من يرى أن العلوم الإنسانية تختلف عن العلوم الطبيعية يقول" في الحقيقة تنطوي العلوم الإنسانية على نمط جلي من الترابطات البنيوية وعلى صيغة فهم. هذه الترابطات

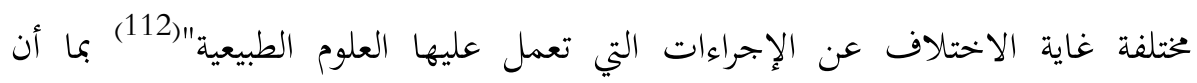

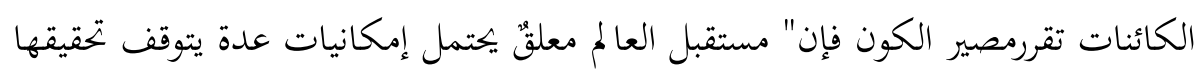

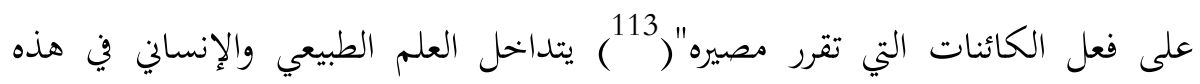
الفلسفة مع وجود فوارق بين العلمين يتصلان بالموضوع والمنهج معاً" أولها: الطبيعة النوعية

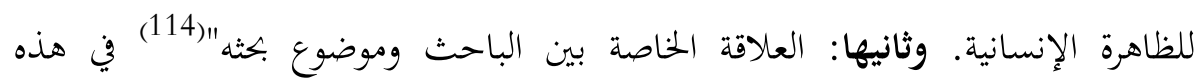
الفلسفة المنهج جاهز وهو منهج العلوم الطبيعية أما عند أصحاب الفنومنولوجيا فإن المنهج

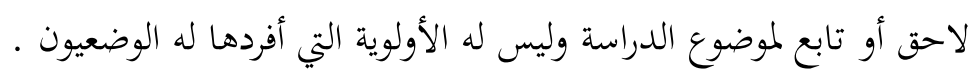




\section{الحاتمة}

وبعد هذه النظرة إلي الفلسفة البراجماتية بند أها تتسم ببعض السمات منها " البراجماتية

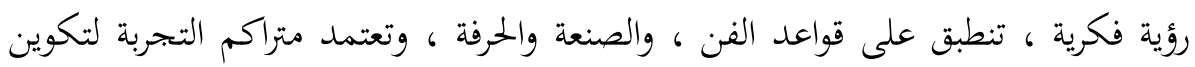

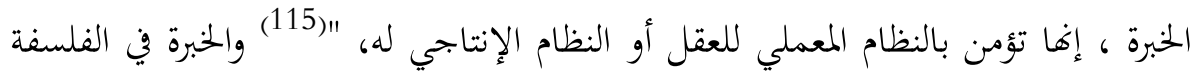

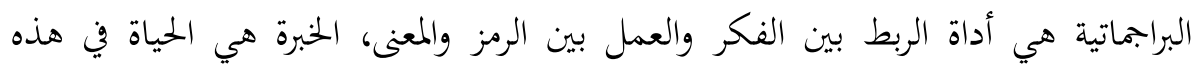

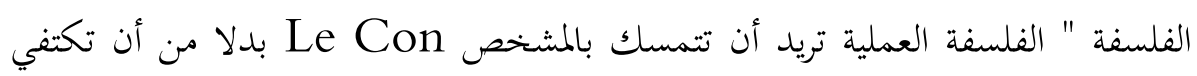
بالنظر إلى المحرد، الفلسفة العملية فلسفة اسمية لا تؤمن إلا بالجزيء أو الفردي؛ أعني أهما

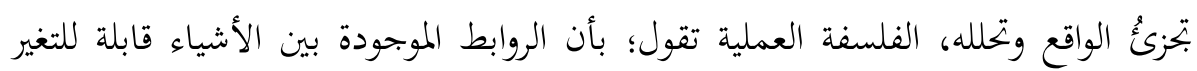
باستمرار ، تتسم الفلسفة العملية بالاعقلية؛ لأن الواقع لا يتطابق دائما مع تصوراتنا

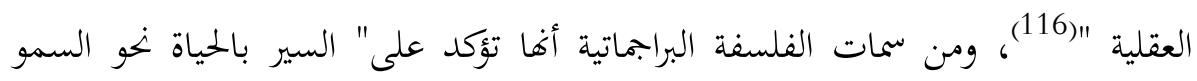
والكمال.

وكانت الفلسفة البراجماتية واحدة من أهم الفلسفات التي أحدثت فعلاً مغايراً في الأنماط

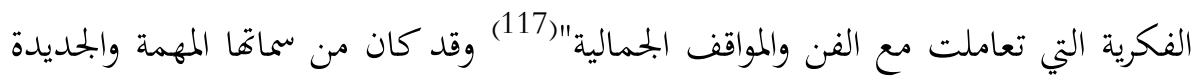
هي استبدالها للنظر من الماضي إلى المستقبل واهتمامها بالرؤية الكلية بدل الجزئية كما كان في الفلسفة الإبحليزية.

ولقد ساهمت الفلسفة البراجماتية في مناقشة عديد القضايا الفلسفية؛ والتي من بينها

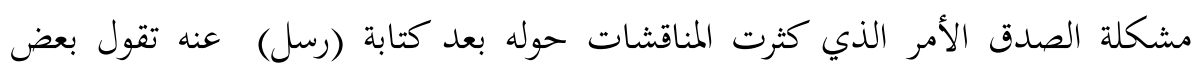
النصـوص في ذلك: " لقد شاع الاهـتمام بمشـكلة الصدق، وكثرت المناقشـات حولها في

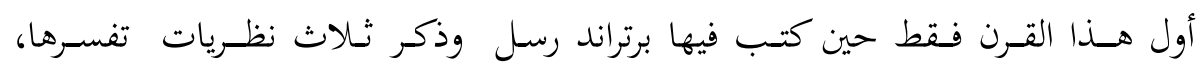

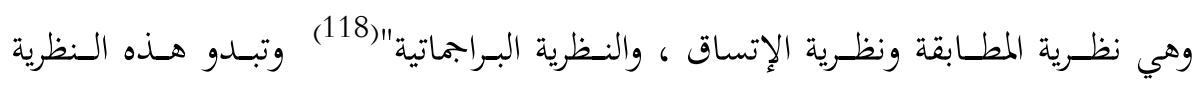
وهي: نظرية المطابقة The Correspondence Theory للصدق في صياغتها البسيطة واضحة وهي:أن القضية تصدق إذا كانت توجد واقعة ما تطابقها، وتكذب

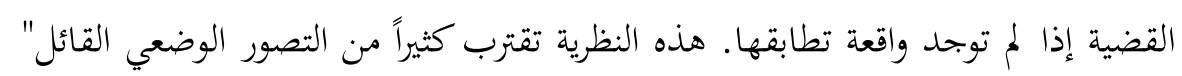


أن القضايا الوحيدة ذات المعنى هي قضايا العلوم، لأغا تتحقق بالمطابقة مع وقائع العالم

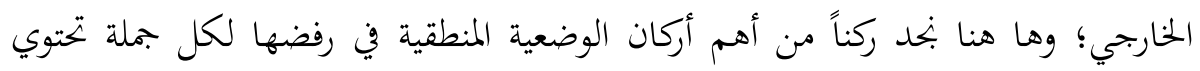

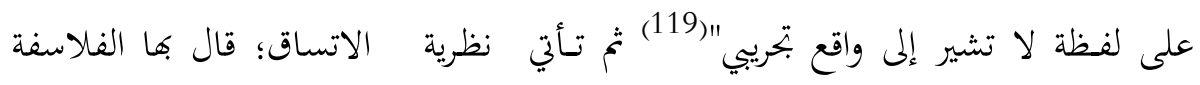
العقلين مثل سبينوزا وتحمس لها بعض فلاسفة الوضعية المنطقية مثل كارل جي همبل ويمكن القول : بأن هذه النظرية تنص على أن وجود الأشياء لا يستقل عن وجود الكائن العاقل الواعي بذاته، أو أن الأشياء على علاقة دائماً بفعل ما ـ ثم تأتي النظرية البرجماتية: وصاحب هذه النظرية هو الفيلسوف (وليم جيمس 1842-1910م) يقول" إن أهم جزء في كتابى براجماتزم هو الحديث عن علاقة الصدق التي يمكن أن تنشأ بين فكرة

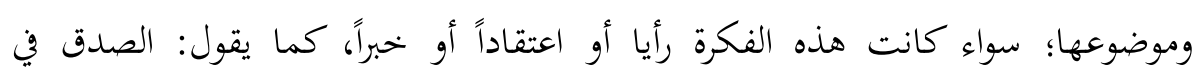
الأفكار هو مطابقتها للواقع، والخطأ فيها عدم مطابقتها له. ويعرف جيمس الصدق: بأنهاء علاقة بين فكرة وواقع خارج على الفكرة، ولهذه العلاقة أساس بتريبي يجعلنا نعرفها تعريفاً

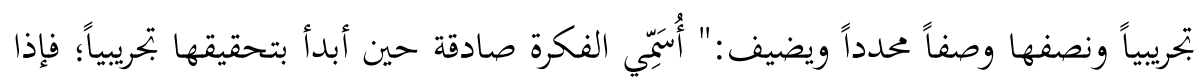
ما تم ذلك سميتها فكرة نافعة "(120)

وبكلمة مختصرة ؛ نقول لقد عالج بيرس في هذه الفلسفة ، كما أوضح هذا البحث عديد المسائل مثل: مفهوم الصدق، والفكرة، وقدم عديد المقولات مثل: مقولة النفس،والخلود، وساهم بشكل فاعل في إصلاح المنطق التقليدي في بعض أجزاء، وقدم نظريات في المنطق وفرام

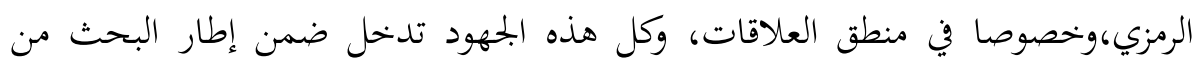

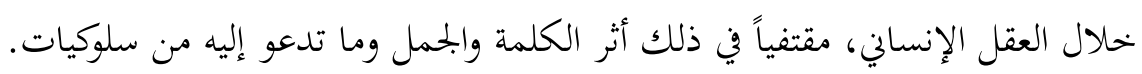




\section{الهوامش}

1- إ · م · بوشنسكي" الفلسفة المعاصرة في أوروبا " ترجمة ، عزّت قرني ، عالم المعرفة ، 165 ، 1992 م، ص 157

2- جورج طرابيشي"معجم الفلاسفة " الطبعة الأولى، دار الطليعة للطباعة والنشر، بيروت، لبنان، 1987 م، ص 198

$$
\text { 4- 3- زكريّا ابراهيم " دراسات في الفلسفة المعاصرة " مكتبة مصر ، القاهرة ، مصر ، ص } 32
$$

5-محمود فهمي زيدان" المنطق الرمزي نشأته وتطوره " مؤسسة شباب الجامعة للطباعة والنشر والتوزيع، الإسكندري، مصر،

$$
\text { 91 198 }
$$

6-حسام محيي الدين الآلوسي" بواكير الفلسفة من الميثولوجيا إلى الفلسفة عند اليونان " الطبعة الأولى ، الدار الدولية للاستمارات

$$
\text { الثقافية. م. م، } 2002 \text { م، ص } 127
$$

7-هنية مفتاح القماطي" نظرية القيمة عند كليرنس لويس" الطبعة الأولى، منشورات، جامعة قاريون،بنغازي، ليبيا،2001

8- هنية مفتاح القماطي" نظرية القيمة عند كليرنس لويس" الطبعة الأولى، منشورات جامعة قاريونس، بنغازي، ليبيا ، 2001 م،

هـ له العديد من النظريات ولكن من أشهر نظرياته البراجماتية التي تذهب إلى أن الفكرة تكون صادقة ما دامت تقود إلى إدراك

$$
9 \text { - الموضوع وأن القضية تكون صحيحة حين يؤدي إقرارها إلى نتائج عملية طيبة تتحقق عن طريق التطبيق . }
$$

10 - إيناس مهدي إبراهيم الصفار" ابعاد الفكر البرجماتي في فن الباو هاوس " بحلة جامعة بابل ، العلوم الإنسانية ، البحلد 22 ،

$$
\text { العدد } 2014 \text { ، ص } 1010
$$

$$
\text { 11- فؤاد كامل" أعلام الفكر الفلسفي المعاصر" الطبعة الأولى، دار الجيل، بيروت، لبنان، 1993م، ص } 97
$$

12- منصور بن عبد العزيز الحجيلي" البراجماتيّة عرض ونقد" Pdf creeted With Pdf Fatory Protrial

Version WWW. Pdffactory. Com .p 278

13- بوخينسكي" تاريخ الفلسفة المعاصرة في أوربا" ترجمة، محمّد عبدالكريم الوافي، منشورات جامعة بنغازي، ص 187 


$$
\begin{aligned}
& \text { 14- منصور عبد العزيز الحجيلي " البراجماتية عرض ونقد "ص } 279 \\
& \text { 15- بوشنسكي " الفلسفة المعاصرة في أوروبا " ص } 158 \text { س } \\
& \text { 16- منصور بن عبدالعزيز الحجيلي " البراجماتية عرض ونقد " مرجع سبق ذكره ص } 278 \\
& \text { • العام الذي صدر فيه كتاب توماس كون بنية الثورات العلمية . }
\end{aligned}
$$

17- عزمي إسلام" ابتحات في الفلسفة المعاصرة " الطبعة الأولى ، وكالة المطبوعات الكويت ، 1980م ، ص 91

$$
18 \text { فؤاد كامل " أعلام الفكر الفلسفي المعاصر " مرجع سبق ذكره ص } 96
$$$$
\text { تشير بعض المراجع إلى أنه قضى الشطر الأخير من حياته في شبه اعتزال حتى مات في فقر نسبي عام } 1914 \text { م }
$$

$$
\text { - } 19 \text { فؤاد كامل " أعلام الفكر الفلسفي المعاصر " مرجع سبق ذكره ص } 95
$$$$
20 \text { منصور بن عبد العزيز الحجيلي " البراجماتية عرض ونقد " مرجع سبق ذكره ص } 279
$$

مه يقول عن التربية " يجب أن قتم بكل فرد حتى يصل الناس إلى تحقيق أفضل وأتم حياة مكنة ومن جهة أخرى يجب أن تساعد

$$
\text { على التجديد الاجتماعي " إيناس الصفار ص } 1025
$$

21 - إيناس مهدي ابراهيم الصفار " أبعاد الفكر البرجماتي في فن الباوهاوس " مرجع سبق ذكره ص 1014

• أثرت الفلسفة البراجماتية في العديد من المناشط مثل : الخحاور التربوية كما عند جون ديوي وكذلك في الأبعاد السياسية كما في

$$
\text { الديمقراطية الأمريكية وكذلك في الأبعاد الفنية كما في فن الباو هاوس (رسم -نحت- نسيج معادن ) . }
$$

22- تشارلز موريس " رواد الفلسفة البراماتية " ترجمة ، إبراهيم مصطفى إبراهيم ، دار المعرفة الجامعية ، طبع نشر توزيع ،

$$
\text { الإسكندرية ، مصر ، } 2011 \text { م ، ص } 23 \text { ـ العنوان الأصلي للكتاب هو : }
$$

The Pragmatic Movement In The American Philosophy

$$
23 \text { - حسام محيي الدين الآلوسي " بواكير الفلسفة "ص } 81
$$

24 - هانز جورج غادامير " بداية الفلسفة " ترجمة ، على حاكم صالح ، حسن ناظم ، الطبعة الأولى ، دار الكتاب الجديد المتحدة،

$$
\text { بيروت ، لبنان ، } 2002 \text { مُ } 26 \text { - محمود زيدان " نظرية المعرفة " مرجع سبق ذكره ص } 15 \text { - هنية مفتاح القماطي " نظرية القيمة عند كليرنس لويس " مرجع سبق ذكره ، ص } 30
$$




$$
28 \text { - } 29 \text { - جميل صليبا " المعجم الفلسفي " الجزء الثاني ، } 2588 \text { - حسام ححيي الدين ص } 77 \text { - } 78
$$

30 -ممود فهمي زيدان " المنطق الرمزي نشأته وتطوره " مؤسسة شباب الجامعة للطباعة والنشر والتوزيع، الإسكندرية، مصر،

$$
92 \text { 1989 م ، ص }
$$

31 -روبير بلانشي " المنطق وتاريخه من أرسطو حتى رسل " ترجمة ، خليل أحمد خليل ، الطبعة الثانية ، بحد المؤسسة الجامعية

$$
32 \text {-للدراسات والنشر والتوزيع ، بيروت ، لبنان ، } 2002 \text { م ، } 398 \text { - } 398 \text { فمود فهي زيدان " المنطق الرمزي "ص } 93
$$

33 -محمّد فتحي الشنيطي " أُسس المنطق والمنهج العلمي " دار النهضة العربية للطباعة والنشر ، بيروت ، لبنان ، 1970 م ، ص

$$
34
$$

$$
\begin{aligned}
& 35 \text {-محمّد مهران " مقدمة في المنطق الرمزي " دار الثقافة للنشر والتوزيع ، القاهرة ، مصر ، } 1991 \text { م ، ص } 315 \\
& 36 \text { - - زيدان المنطق الرمزي ص } 100 \\
& 37 \\
& 38 \text {-زيدان المنطق الرمزي ص } 94 \\
& \text { • الحد لا يختمل الصدق أو الكذب }
\end{aligned}
$$

هـ القضية تحتمل الصدق والكذب بمعنى قد تكون صادقة وقد تكون كاذبة

39 -زيدان المنطق الرمزي 94

$$
40 \text {-زيدان المنطق الرمزي ص } 95
$$

$$
42 \text { - } 41 \text { - زيدوبير بلانشي " المنطق وتاريخه " مرجع سبق ذكره ، ص } 398
$$




$$
317 \text { - محمّد مهران ص } 317
$$

45 -زكي نجيب محمود " حياة الفكر في العالم الجديد " دار الشروق ، ص 115

$$
46 \text { - حسام ميي الدين الآلوسي " بواكير الفلسفة "ص } 115
$$

$$
47 \text { - المرجع نفسه زكي بنيب محمود ص } 118
$$

48 - جورج طرابيشي " معجم الفلاسفة " الطبعة الأولى ، دار الطليعة للطباعة والنشر ، بيروت ، لبنان ، 1987 م ، ص 198 ه الجملة العانس في تصوري هي الجملة التي لا تفهم في ذاتما ولا تفتح آفاقاً جديدة .

$$
49
$$

50 - محمود زيدان " نظرية المعرفة عند مفكري الإسلام وفلاسفة الغرب المعاصرين " الطبعة الأولى ، دار النهضة العربية ، بيروت ،

$$
\text { لبنان ، } 1989 \text { م ، ص } 23
$$

$$
51 \text { - -حسام حيي الدين " بواكير الفلسفة "ص } 53
$$

25 - محمود زيدان نظرية المعرفة ص 52

$$
53
$$

$$
54 \text {-فؤاد كامل " أعلام الفكر الفلسفي المعاصر " مرجع سبق ذكره ص } 97
$$

• قراءة بيرس للفيلسوف الأمريكي شيلر وقراءة لكانت لمدة تزيد على أربعة أعوام ولكنه تحول عنها في سنة 1868 م ثم قراءة

$$
\text { للفيلسوف الانخليزي توماس ريد وغيره . }
$$

$$
\begin{aligned}
& 55 \text {-منصور بن عبد العزيز الحجيلي " البراجماتية عرض ونقد "ص } 282 \\
& 56 \text {-محمود زيدان " نظرية المعرفة " مرجع سبق ذكره، ص } 121 \\
& 57 \text {-حسام محي الدين الآلوسي " بواكير الفلسفة "ص } 110 \\
& 58 \text { - بوشنسكي ص } 158
\end{aligned}
$$

59 -هنية مفتاح القماطي"نظرية القيمة عند كليرنس لويس" مرجع سبق ذكرهص 14

$$
60
$$

61 -محمود زيدان " نظرية المعرفة " مرجع سبق ذكره، ص 120 


$$
62
$$

لهذا الفيلسوف العديد من النظريات منها : نظرية في فلسفة اللغة يسميها نظرية السميوطيقا أو نظرية العلامات ، وله نظريات في

إطار الفلسفة الظاهراتية ، . كما شارك في إقامة المنطق الرياضي .

$$
97 \text { فؤواد ص } 63
$$

64 -منصور بن عبد العزيز الحجيلي " البراجماتية عرض ونقد "ص 283

$$
65 \text {-إيناس مهدي الصفار ص } 1017 \text { - } 1018
$$$$
\text { • هي المعاني العامة البحردة . }
$$

$$
66 \text { - } 66
$$

$$
6768 \text { - جميل صليبا " المعجم الفلسفي " دار الكتاب اللبناني ، بيروت ، لبنان ، الجزء الأول ص } 104 \text { صحيي الدين الآلوسي " بواكير الفلسفة " مرجع سبق ذكره ص } 115
$$

69 - ياسين خليل "منطق المعرفة العلمية"منشورات الجامعة الليبية كلية الآداب ، الجزء الأول من نظرية العلم ، 1971 م،ص 152

$$
\begin{aligned}
& 70 \text {-جميل صليبا " المعجم الفلسفي " الجزء الثاني ، ص } 398 \\
& 71 \text { - يوسف كرم " تاريخ الفلسفة الحديثة "ص } 417 \\
& 72 \text {-فؤاد كامل " أعلام الفكر الفلسفي المعاصر " مرجع سبق ذكره ص } 99 \\
& 73 \text {-منصور بن عبد العزيز الحجيلي " البراجماتية عرض ونقد "ص } 279 \\
& 74 \text {-إيناس مهدي الصفار ص } 1017 \\
& 75 \text {-زكي نجيب محمود " حياة الفكر في العالم الجديد " مرجع سبق ذكره } 122 \\
& \text { • من الداعين الأوائل لتأسيس علم اليوجينيا Eugenics علم تحسن النسل البشري } \\
& 76 \text { - هنية القماطي " نظرية القيمة عند ليرنس لويس " مرجع سبق ذكره ، ص } 32 \\
& 77 \text {-زكي بنيب محمود " حياة الفكر في العالم الجديد " مرجع سبق ذكره ص } 121 \\
& 78 \text {-هنية مفتاح القماطي " نظرية القيمة عند كليرنس لويس " مرجع سبق ذكره ، ص } 44 \\
& 79 \text { - هانز غادامير " بداية الفلسفة " ص } 37
\end{aligned}
$$


80 -إيان هاكينج " الثورات العلمية " ترجمة ، السيد نفادي ، دار المعرفة الجامعية ، الاسكندرية ، مصر ، 1996 م ، 58

$$
81 \text { - ابراهيم مذكور " دراسات فلسفية "ص295 - 295 }
$$

هـ العبارة تكون ذان معنى لو كانت كل كلمة فيها مما يككن تحويله 'لى سلوك وعمل ويكون معيار صدق العبارة هو : عدم وجود

كلمة لا ندري ماذا يكون السلوك الذي هو معناها فإذا وجدت هذه الكلمة فسدت العبارة بأسرها وأصبحت كلاماً خالياً من الدلالة .

$$
\begin{aligned}
& 82 \\
& 83 \\
& 84 \text {-هنية مفتاح القماطي " نظرية القيمة عند كليرنس لويس " مرجع سبق ذكره ، ص } 18 \\
& \text { • ظهرت تجربة القطار لأول مرة في تبسيط آينشتين لنظرية النسبية . } \\
& 85 \text {-إيان هاكينج " الثورات العلمية " مرجع سبق ذكره } 27 \\
& 86 \text {-يوسف كرم " تاريخ الفلسفة الحديثة "ص } 418 \\
& 87 \text {-بوشنسكي ص } 158
\end{aligned}
$$

ه تقوم براجماتيته على " ثلاثة دعائم أساسية : 1- الحقيقة الأولانية Apriori تنشأ تحليل التصورات ، كما أفا محددة في طبيعتها

2 - اختيار الأنساق التصورية لتطبيقها على الحبرة لضرورة أداتية Instrumental براجماتية ، كما إن الحقيقة لا تزيد عن كوفا احتمال 3-

$$
\begin{aligned}
& \text { إن الخبرة قابلة للتفسير التصوري ، وإذا لم تكن كذلك فلا يككن إدراكها " القماطي ص } 16 \\
& 88 \text {-هنية مفتاح " نظرية القيمة عند كليرنس لويس " ص } 12 \\
& 89 \\
& 90 \\
& 91 \\
& 92 \\
& 93 \text {-زكي نجيب ص } 130 \\
& 94 \\
& 95
\end{aligned}
$$


• وهو عند بيرس : رغبة الانتقال من حالة الشك إلى حالة الاعتقاد

96 -منصور بن عبد العزيز الحجيلي " البراجماتية عرض ونقد "ص 284

" المقولة هي المحمول ، ووجه إطلاقها على المحمول كون المحمول في القضية مقولاً على الموضوع " معجم صليبا الجزء الثاني ص

$$
\text { } 97
$$

98 -جميل صليبا " المعجم الفلسفي " الجزء الأول ، ص 128

ه تشير بعض المراجع إلى أن " أفلاطون لا يبدي تعزيزاً للمجادلات النظرية لإثبات خلود النفس " غادامير ص 59

$$
99 \text {-جميل صليبا المعجم الفلسفي ، الجزء الثاني ، ص } 481 \text {-هانز جورج غادامير " بداية الفلسفة "ص } 61 \text { - } 2100
$$

101 -هانز جورج غادامير " بداية الفلسفة " ترجمة ، على حاكم صالح ، حسن ناظم، الطبعة الأولى، دار الكتاب الجديد المتحدة،

$$
\text { بيروت، لبنان ، } 2002 \text { م ، ص } 57
$$

$$
102 \text {-هانز غادامير " بداية الفلسفة "ص } 63
$$

$$
103 \text {-جميل صليبا " المعجم الفلسفي " الجزء ، الأول ، ص } 544
$$

104 -هانز جورج غادامير " بداية الفلسفة " ترجمة ، على حاكم صالح ، حسن ناظم ، الطبعة الأولى، دار الكتاب الجديد المتحدة،

$$
\text { بيروت ، لبنان ، } 2002 \text { م ، ص } 55
$$

105 -حسين حرب " الفكر اليوناني قبل أفلاطون " الطبعة الأولى ، دار الفكر اللبناني ، بيروت ، لبنان / 1990 م ، ص 50

106 - ميخائيل ماركوفيتش فيليتشيك " الأسس البيولوجية للشيخوخة وطول العمر " ترجمة ، زهير إبراهيم جبور ، الطبعة الأولى ،

دار الكتاب الجديد المتحدة ، بيروت ، لبنان ، 2000 م ، ص 9

107 - حسام محيي الدين الآلوسي " بواكير الفلسفة من الميثولوجيا إلى الفلسفة عند اليونان " الطبعة الأولى ، الدار الدولية

$$
\text { للاستثمارات الثقافية ش · م · م ، } 2002 \text { م ، ص } 273
$$


108 -غادامي " بداية الفلسفة "ص 82

109 -فؤاد كامل ص 103

110

111 -ابراهيم مذكور . تصدير " دراسات فلسفية " دار الثقافة للطباعة والنشر، القاهرة، مصر ، 1979 م، ص 293

112 -هانز جورج غادامير " بداية الفلسفة " ترجمة، على حاكم صالح، حسن ناظم ، الطبعة الأولى، دار الكتاب الجديد المتحدة ،

بيروت ، لبنان ، 2002 م ، ص 27

113 -يوسف كرم " تاريخ الفلسفة الحديثة "ص 418

114- مذكور ص 294

115- إيناس الصفار ص 1014

116 -زكريا إبراهيم " دراسات في الفلسفة المعاصرة " مكتبة مصر ، القاهرة ، مصر ، ص 29 -31

117 -إيناس مهدي إبراهيم " أبعاد الفكر البراجماتي في فن الباو هاوس " مرجع سبق ذكره ص 1011

118 -محمود زيدان " نظرية المعرفة " مرجع سبق ذكره ص 131

119 -حسام محي الدين الآلوسي "بواكير الفلسفة "ص 114

120 - 120 


\section{قائمة المراجع}

1- إبراهيم مذكور" دراسات فلسفية " دار الثقافة للطباعة والنشر، القاهرة، مصر، 1979م. 2- إيناس مهدي ابراهيم الصفار" أبعاد الفكر البرجماتي في فن الباوهاوس " بحلة جامعة بابل،

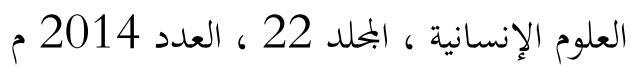
3- إيان هـاكينج" الثورات العلمية " ترجمة، السيد نفادي، دار المعرفة الجامعية، الإسكندرية،

$$
\text { مصر ، } 1996 \text { م } 1996
$$

4- إ. م · بوشنسكي " الفلسفة المعاصـرة في أوربـا " ترجمـة، عزّّت قرني، عـالم المعرفـة 165، 1992

5- بوخنسكي" تاريخ الفلسفة المعاصرة في أوربا " ترجمة، محمّد عبد الكريم الوافي، منشورات جامعة بنغازي 6- تشــارلز مـوريس" رواد الفلسـفة البراجماتيـة" ترجمـة، إبـراهيم مصـطفى إبـراهيم، دار المعرفـة

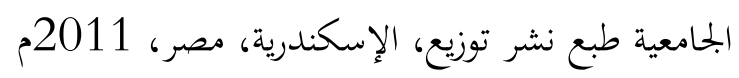

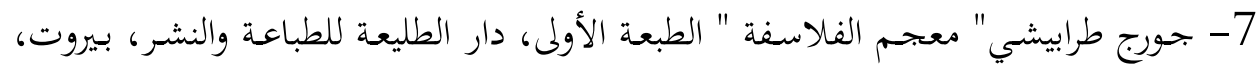
لبنان، 1987 م. 198 م. 8- جميـل صـليبا " المعجـم الفلسـفي" الطبعـة الأولى، الشـركة العامـة للكتـاب، دار الكتــاب اللبناني، بيروت، لبنان، 1982 م الجزء الثاني.

9- حسـام محيي الدين الألوسي" بـواكير الفلسفة مـن الميثولوجيـا إلى الفلسفة عنداند اليونـان "

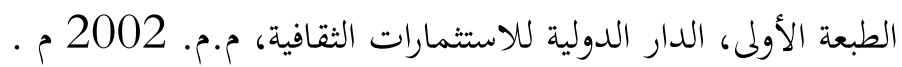

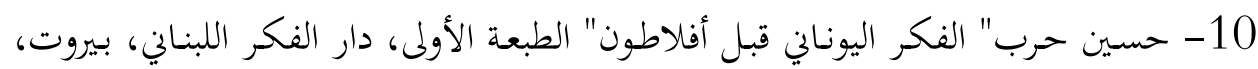
لبنان، 1990م. 
11- روبير بلانشي " المنطق وتاريخه مس أرسطو حتى رسل " ترجمة ، خليـل أحمد خليل ،

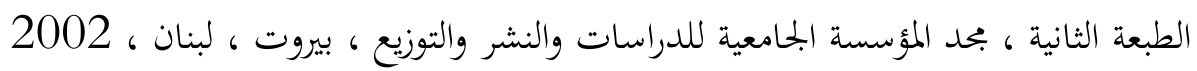

12- زكريا إبراهيم " دراسات في الفلسفة المعاصرة " مكتبة مصر ، القاهرة ، مصر

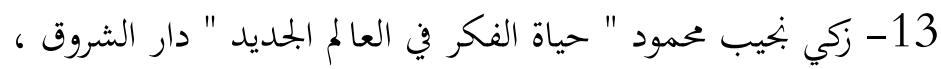
14- عزمي إسلام " ابتاهات في الفلسفة المعاصرة " الطبعة الأولى ، وكالة المطبوعات الكودياه . 1980 ، 15- فؤاد كامل " أعلام الفكر الفلسفي المعاصر " الطبعة الأولى ، دار الجبل ، بيروت ، لبنان م 1993 ،

$$
\text { 16- منصور عبد العزيز الحجيلي " البراجماتية عرض ونقد " }
$$

17- محمود فهمي زيدان " نظرية المعرفة عند مفكري الإسـلام وفلاسفة الغرب المعاصرين "

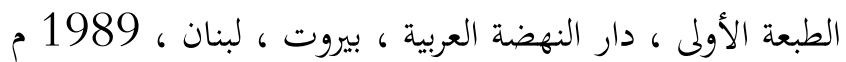

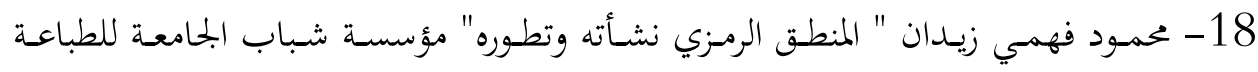

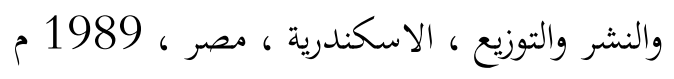

19- محمّد فتحي الشنيطي " أُسس المنطق والمنهج العلمي" دار النهضة العربية للطباعة والنشر،

بيروت ، لبنان ، 1970 م 1970

20- محمّـد مهـران" مقدمــة في المنطـق الرمـزي" دار الثقافـة للنشـر والتوزيـع، القـاهرة، مصـر،

21- ميخائيل ماركوفيتش فلينتشيك" الأسس البيولوجية للشيخوخة وطول العمر" ترجمة، زهير

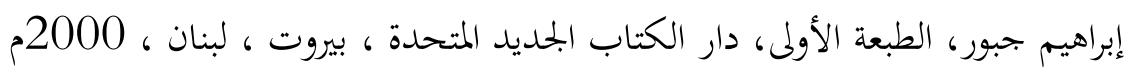

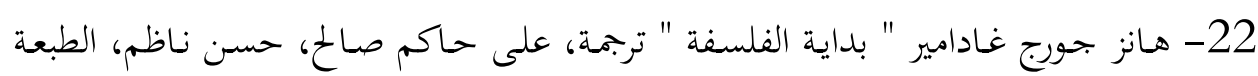

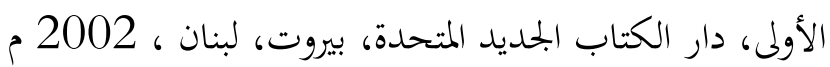




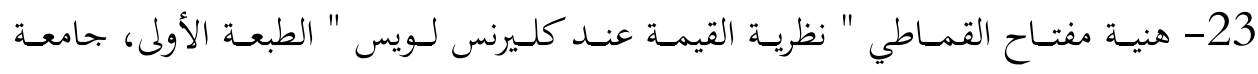

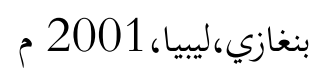

24- ياسين خليل " منطق المعرفة العلمية " منشورات الجامعة الليبية كلية الآداب، الجزءء

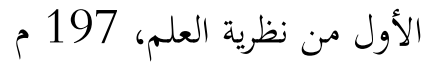

25- يوسف كرم " تاريخ الفلسفة الحديثة " دار المعارف، القاهرة، مصر المر لنارية 